\title{
Medicinal plants as therapeutic options for topical treatment in canine dermatology? A systematic review
}

\author{
Milena Tresch', Meike Mevissen ${ }^{1}$, Hannah Ayrle ${ }^{2}$, Matthias Melzig ${ }^{3}$, Petra Roosje $^{4}$ and Michael Walkenhorst ${ }^{2 *}$ (D)
}

\begin{abstract}
Background: Medicinal plants have been used traditionally since centuries for wound care and treatment of skin diseases both in human and animals. Skin diseases are one of the most common reasons for owners to take their dog to the veterinarian. The demands for treatment and prophylaxis of these diseases are broad. A wide range of bacteria including antibiotic-resistant bacteria can be involved, making the treatment challenging and bear an anthropo-zoonotic potential. The aim of this review is to systematically evaluate based on recent scientific literature, the potential of four medicinal plants to enrich the therapeutic options in pyoderma, canine atopic dermatitis, otitis externa, wounds and dermatophytosis in dogs.

Results: Based on four books and a survey among veterinarians specialized in phytotherapy, four medicinal plants were chosen as the subject of this systematic review: Calendula officinalis L. (Marigold), Hypericum perforatum L. agg. (St. John's Wort), Matricaria chamomilla L. (syn. Matricaria recutita L., Chamomile) and Salvia officinalis L. (Sage). According to the PRISMA statement through literature research on two online databases a total of 8295 publications was screened and narrowed down to a final 138 publications for which full-text documents were analyzed for its content resulting in a total of 145 references (21 clinical, 24 in vivo and 100 in vitro references).

Conclusions: All four plants were proven to have antibacterial and antifungal effects of a rather broad spectrum including antibiotic-resistant bacteria. This makes them an interesting new option for the treatment of pyoderma, otitis externa, infected wounds and dermatophytosis. Marigold, St. John's Wort and Chamomile showed woundhealing properties and are thus promising candidates in line to fill the therapeutic gap in canine wound-healing agents. St. John's Wort and Chamomile also showed anti-inflammatory and other beneficial effects on healthy skin. Due to the wide range of beneficial effects of these medicinal plants, they should be taken into account for the treatment of dermatologic diseases in dogs at least in future clinical research.
\end{abstract}

Keywords: Dog, Dermatology, Calendula officinalis L., Hypericum perforatum L., Matricaria chamomilla L., Salvia officinalis L., Topical treatment

\section{Background}

Skin diseases are one of the most common reasons for owners to take their dog to the veterinarian $[1,2]$. Canine skin diseases include bacterial skin infections, hypersensitivity disorders, canine atopic dermatitis (CAD), food adverse reactions, otitis externa, wounds, dermatophytosis, neoplasia and parasitic infestations [2, 3]; a range of diseases with various etiologies and symptoms and thus

\footnotetext{
* Correspondence: michael.walkenhorst@fibl.org

${ }^{2}$ Department of Livestock Sciences, Research Institute of Organic Agriculture

(FiBL), Ackerstrasse 113, Postbox 219, 5070 Frick, Switzerland

Full list of author information is available at the end of the article
}

diverse demands for treatment. An overview of these diseases with their possibly involved pathogens, pathogenesis and pathophysiology and demands for therapy and prophylaxis is presented in Table 1.

Primary and secondary bacterial skin- and ear infections frequently occur in dogs. Staphylococcus pseudintermedius is the most common pathogen isolated from primary pyodermas as well as secondary skin and ear infections in dogs suffering from CAD or food allergies $[4,5]$ and carriage of methicillin-resistant S. pseudintermedius (MRSP) appears to be a risk factor for surgical site infections in dogs [6]. In addition, the opportunistic pathogen

(c) The Author(s). 2019 Open Access This article is distributed under the terms of the Creative Commons Attribution 4.0 International License (http://creativecommons.org/licenses/by/4.0/), which permits unrestricted use, distribution, and 


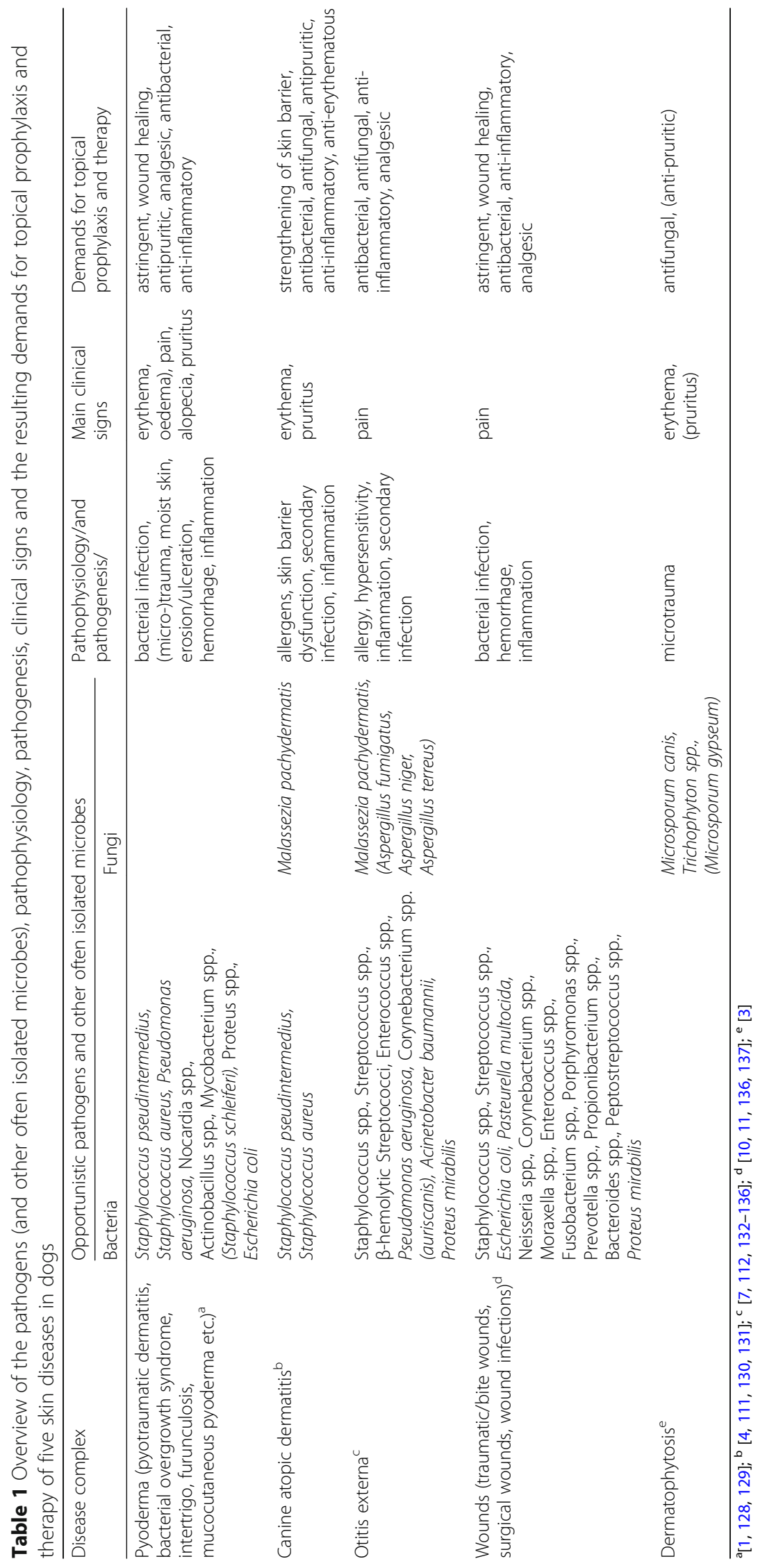


Pseudomonas aeruginosa is frequently isolated from ear infections and pyodermas in dogs as well [7].

Thus topical and oral antibiotics are frequently used in canine bacterial skin, ear and wound infections and the occurrence of resistance is a major concern. An increasing antimicrobial resistance in bacteria of the Staphylococcus intermedius group, isolated from clinical samples from dogs and cats has been reported [8]. Similar observations were reported for P.aeruginosa [7].

Treatment of infections associated with antimicrobial resistant bacteria can be very challenging. Moreover, the close contact between animals and their owners provides opportunities for microbial exchange, including MRSP or multi-drug resistant (MDR) pathogens [9]. It is therefore crucial to reduce the use of antibiotics and prevent further emergence of antimicrobial resistance and develop new antimicrobial therapies or develop measures that prevent microbial overgrowth. Microbial overgrowth is often associated with impaired epidermal barrier function such as seen in CAD. Therefore treatments that combine antimicrobial effects and anti-inflammatory or epidermal barrier enhancing effects would be even more desirable.

An additional emerging problem is the reported tolerance to the frequently used biocide chlorhexidine gluconate (CHG) solution which has been observed for some Gram-negative bacteria. Although mostly still effective against Gram-positive bacteria a recently confirmed link between antibiotic resistance and use of CHG demands for stewardship on the use of important biocides and thus there is a need for alternatives to the current biocides.

Another field affected by bacterial infections is wound care. The range of bacteria that can be found in infected wounds, especially bite wounds, is broad [10]. This makes exploring new treatment options like plant extracts interesting, even more so as medicinal plants consist of a mix of several compounds that may act against a broad spectrum of bacteria. However, not only infected wounds originating from injuries could profit from plant based antimicrobial agents but also certain surgical site infections. The latter can be associated with antimicrobial susceptible organisms but also MRSP or MDR pathogens $[6,11]$. Also in the field of wound care there is a demand for new effective treatment options. Geriatrics and gerontology are of increasing importance in small animal care and even though the dogma that cutaneous wound healing is impaired as a function of age is not proven in dogs, structural and functional changes in the skin have been reported $[12,13]$.

Patients with impaired wound healing could benefit from substances supporting the healing process. Similarly, patients suffering from CAD could benefit from treatments which do not only fight bacterial and or yeast overgrowth/ infections but which also strengthen the skin barrier. While there are disinfectants and antibiotics registered for wound care, there are no registered veterinary drugs e.g. on the Swiss market (www.clinipharm.ch) which aid wound-healing itself.

Dermatophytosis in dogs occurs less frequently but is important because of its zoonotic potential [3]. Although current treatments are generally effective [3], additional treatment [14] options could be beneficial.

As numerous plant species have been used traditionally in Switzerland and other European countries for the treatment of various skin diseases including wounds [15-17], it might be an interesting option to look for alternative treatments in plant extracts. The goal of this review is thus to systematically evaluate the potential of four medicinal plants to enrich the therapeutic options in five relevant fields of canine dermatology: pyoderma, CAD, otitis externa, wounds and dermatophytosis.

\section{Methods}

The methods of this systematic review are in accordance with the design of study by Ayrle et al. [18] and are based on the recommendations of the PRISMA statement $[19,20]$ and the AMSTAR measurement tool [21]. The PICOS scheme [19] was used to design the research question: the population are dogs, the intervention is a topical treatment with medicinal plants, the comparator is no treatment, a placebo or standard treatment, the outcome is the effect of the plant, the study design includes in vitro, ex vivo, in vivo or clinical trials. A detailed description of the systematic review is given in the Additional file 1.

\section{Selection of plant species}

Four recent books on veterinary phytotherapy [15, 22-25] were manually screened by one person. Each plant mentioned as a remedy for dermatologic problems of any kind was listed and for each plant the number of books in which it was listed as such was counted. In order to also include the expertise and experience of specialists in the selection of plant species, a non-representative survey was conducted on veterinarians specialized in phytotherapy attending a conference in 2016. The 30 participants were given five minutes of time and were asked to spontaneously write down a maximum of ten plants they used most frequently as phytotherapeutic agents for dogs. They were also asked to give indications for their use. The received answers were filled into a table where each plant mentioned was listed together with the field of indication according to the ATCvet code [26]. A table describing the results of the screening of the books and the survey is accessible in Additional file 2.

The plants which were listed as therapeutic agent in dermatology in all four books or which were mentioned as such in three books and which were listed according to the ATCvet code D at least once in the survey, were 
included. The plants mentioned as dermatologically relevant therapeutic agents in all four books were Matricaria chamomilla L. (Chamomile) and Calendula officinalis L. (Marigold). Chamomile also has been mentioned by three contestants of the survey according to the ACTvet code D, and Marigold was mentioned four times. Salvia officinalis L. (Sage) was listed in three books and it was also mentioned according to the ATCvet code $\mathrm{D}$ three times in the survey. Hypericum perforatum L. agg. (St. John's Wort) was listed in three books and was mentioned as a skin remedy by one contestant of the survey.

\section{Selection of scientific references Literature search}

For each of the previously selected plants an online bibliographic literature search was conducted. An introduction in scientific literature research was provided by a professional librarian. The databases used were PubMed [27] and Web of Science [28]. The literature search using these databases was conducted between 2017 and 05-03 and 2017-05-11 by one person. The search was limited on peer-reviewed publications published between 1997-01-01 and 2017-04-30. The search terms for the keyword search in both databases consisted of the Latin name of the plant, the English trivial names and the pharmaceutical denomination in Latin (e.g. Salvia officinalis OR Sage OR salviae officinalis folium). In the PubMed keyword search, the results were refined with the subjects "complementary medicine", "systematic review", "toxicology" and "veterinary science". In the Web of Science keyword search the results were refined with the research areas "pharmacology pharmacy", "integrative complementary medicine", "toxicology", "mycology", "dermatology", "veterinary sciences", "infectious diseases", "microbiology", "virology". In PubMed an additional MeSh-Term search was performed with the MeSh-Term of each plant (Latin name) and the subheadings "adverse effects", "drug effects", "microbiology", "pharmacology", "therapeutic use" and "toxicity".

The use of plant extracts as anti-parasitic agents and in cancer therapy was not investigated as this would have exceeded the extent and the purpose of this review.

\section{Keyword search within EndNote}

For each plant species, a term-list search was conducted. Only references containing the word truncations "anti", "astring", "bioactiv", "canin", "constitu", "derma", "dog", "eff", "immune", "pharma" or "wound" in their title or abstract were included. References containing "intest", "gastro", "pulmo", "broncho", "tumor" or "cancer" in their title or abstract were excluded.

\section{Manual sorting of references according to in- and exclusion criteria}

In order to further determine which publications were to be included in this review, the titles of the remaining publications were screened manually by one person and an in- or exclusion was made according to predefined in- and exclusion criteria. The references still included after the manual screening of the titles were screened and in- or excluded again by reading the abstract and applying the same criteria as stated above for the screening of titles.

\section{In- and exclusion criteria}

The in- and exclusion criteria were partially self-developed (based on Table 1) and partially derived from the publication by Ayrle et al. [18].

Only peer reviewed publications including an abstract written in English were considered. In order to be included, publications had to deal with an assessment of plants in vitro, ex vivo, in vivo or in a clinical trial and/ or the topical use of plants and/or their extracts AND antimicrobial (antibacterial, antiviral or anti-mycotic) effects, anti-inflammatory effects, astringent effects, wound healing, epithelial proliferative or fibroproliferative effects, antipruritic effects, analgesic effects, other beneficial effects on the skin (e.g., anti-edematous, protective against water loss etc.), wound treatment, skin infections (bacterial, mycotic, viral), pruritus, otitis externa, seborrhea, $\mathrm{CAD}$ and other skin conditions occurring in dogs or being comparable to skin conditions occurring in dogs or dealing with disinfectant properties.

Publications dealing with ingredients, constituents, components of plants and detection or extraction of them were classified as "pharmacognostic publications", and these were collected in a separate folder in EndNote for each plant. Publications referring to adverse effects or toxic effects of plants were classified as "publications on unwanted adverse effects" and were also collected in a separate folder in EndNote for each plant. Publications reviewing publications were also collected in a folder for each plant as "review publications".

Publications without an abstract, which were only presented on conferences and not in peer-reviewed journals, investigating a mixture of different plant species in a combined preparation or dealing with other plant species than we focused on, were excluded. Also further publications were excluded: publications dealing with pathogens other than the main or closely related pathogens connected with dermatological disease in dogs (as shown in Table 1), plants used as food, plant genetics, cultivation or breeding of plants, plant pathology, plant protection systems or pesticides, ecology, geology, ethology, sociology, ethnobotany, food technology or food packaging, the use of the plant as a repellent, insecticide 
or anti-parasitic agent, homeopathic use of the plants (excluding mother tinctures, which were included), any anti-inflammatory or analgesic effects of a topically used plant that is not intended for skin problems (e.g. cream preparations for topical arthritis or migraine treatment), the effects of the plants and their extracts on endothelial cells, anti-inflammatory effects and effects on inflammatory cells but not explicitly connected to their role in the skin, effects of endophytic fungi and their products found in/on the plants, antiangiogenic properties if not connected directly to the skin or wound healing or the nutritional or mineral content of the plants.

\section{Classification}

Subsequently, the included (left over) publications were divided into the four groups "pharmacognostic publications", "publications on adverse effects", "review publications" and "finally included publications" (accessible in Additional file 3).

For the "finally included publications" the full text was acquired. One publication was excluded as the full text was not available.

Prior to filling the information of the "finally included publications" in a table (Additional file 3), a distinction between "finally included publication" and "reference" was made:

Finally included publication: one scientific publication

Reference: one or several clinical, in vivo or in vitro trial(s) of one plant species within one finally included publication (one line in Additional file 3). The references were classified into either "clinical", "in vivo" or "in vitro" references. References investigating skin diseases occurring naturally in the investigated animal species (including human) were defined as "clinical references". References investigating skin diseases and the effect of plants in human or animal models were categorized as "in vivo" references. Studies using pathogens, cell layers or ex vivo models were categorized as "in vitro" references. According to this definition, one finally included publication can contain several references (e.G. a publication on the same in vitro trial using several plants, e.G. Marigold, chamomile and sage, results in three references and one publication describing an in vitro and an in vivo trial with one plant species results in two references.) a publication reporting on several trials of the same category (clinical, in vivo, in vitro) results in one reference.

\section{Scoring system}

Based on the pre-defined demands for therapy and prophylaxis as described in Table 1, several possible effects of the plants and their extracts were added to the table (Additional file 3) as rows. If a reference showed one of these effects to be proven in a statistically significant way, it was marked as a "proven reference" and as a "+" in the table. If the reference was not able to show that an effect was proven or if the results were not statistically significant, it was marked as a "disproven reference" and as a "0" in the table. Uncertain effects presented in references (e.g. if the effect was not seen consistently) or if the reference did not state a clear result concerning that effect, these references were marked as an "uncertain reference" and a "?" in the table. If a reference showed the opposite of an effect (e.g. anti-angiogenic instead of pro-angiogenic) it would be marked as an "opposite reference" and a "-" in the table.

Ultimately, for each plant and each effect, the amounts of proven, disproven, uncertain and opposite references were counted and the results were presented.

\section{Results}

Of the 8295 publications retrieved from databases, a final total of 138 publications were selected to be filled in the table, accessible in 'Additional file 3', resulting in a total of 145 references. The selection process of publications to be included into this table is described in Fig. 1 and a more detailed description of the number of publications found and included after different steps is provided in Table 2 .

Figure 2 illustrates the distribution of the publication dates for each plant species over the 20 years included in this review in two-year-steps. For all plant species an increasing number of publications could be found for the last decade compared to the time period between 1997 and 2007.

For each plant, the amount of total references resulting from the included publications and their distribution into clinical, in vivo and in vitro references is presented in Fig. 3. Most publications were included for St. John's Wort and the most references resulted for this plant. Marigold was the plant with the least publications and references, but had the greatest percentage of in vivo and clinical trials. The highest percentage of in vitro references was found for Sage. Table 3 presents the number of in vitro and clinical/in vivo references which confirm ("+"), do not give a clear result for ("?"), do not confirm ("0"), or which show the opposite of ("-") each of the total 16 effects required for the treatment of canine skin diseases. Overall, references showed seven times the opposite of the required effects while 198 times references were able to prove the required effect. Topical antibacterial, anti-fungal, anti-inflammatory and anti-erythematous effects were described in references of all four plants investigated. St. John's Wort and Sage were the plants with the highest number of references 


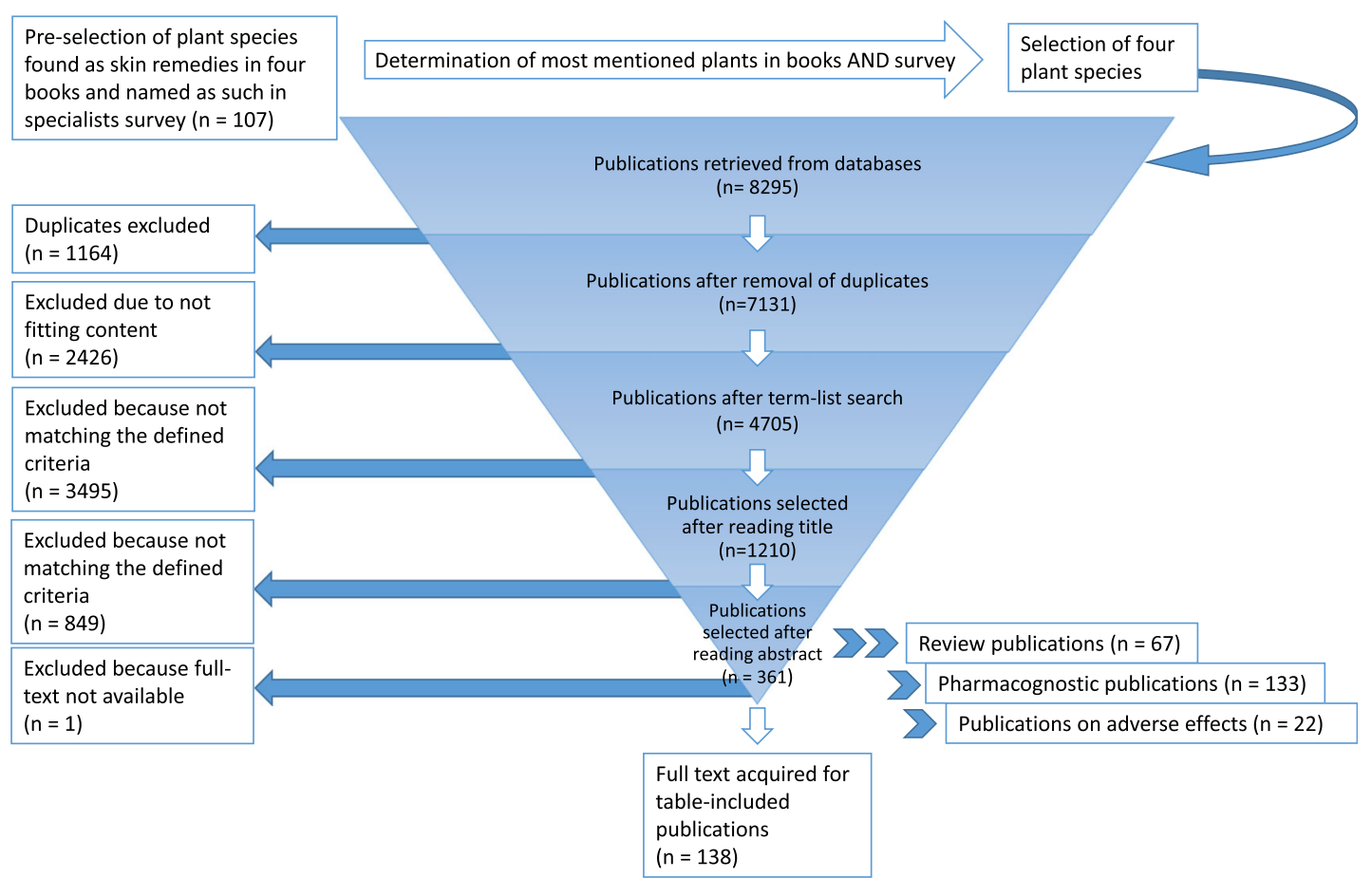

Fig. 1 Process of the systematic literature review

investigating antibacterial effects and they were the only ones for which the activity against biofilms was studied and confirmed. Synergistic activities of plant extracts with antibiotics or disinfectants were only investigated for Chamomile and Sage. Sage was the only plant for which no studies related to wound-healing potential were found. For St. John's Wort and Chamomile, publications investigating and showing analgesic effects were found.

In the category "hypothesis proven", various skin relevant effects were shown (Additional File 3). For Marigold, these effects included an increased expression of connective tissue growth factor and $\alpha$-smooth muscle actin which was shown in an in vitro [29] as well as in an in vivo study [29], the increased expression of hyaluronic acid in human dermal fibroblasts and a protective effect against the induction of irritant contact dermatitis [30]. For St. John's Wort, a protective effect on hair follicles and collagen was shown if applied directly after thermal burns [31]. Another study proved an inhibitory effect on hypodermal stasis in burn wounds indicating a protective effect on the perfusion in this area, preventing it from further damage through ischemia [32]. Two references reported an inhibitory effect of St. John's Wort extract and hyperforin on the allostimulatory capacity of epidermal cells in vivo and in vitro, thus proving to decrease the epidermal cells' $(\mathrm{EC})$

Table 2 Overview of the amount of scientific publications collected for each plant species after each step of the review process

\begin{tabular}{lllll}
\hline Plant name (Latin) & Calendula officinalis & Hypericum perforatum & Matricaria chamomilla & Salvia officinalis \\
\hline Plant name (English) & Marigold & St. John's Wort & (German) Chamomile & Sage \\
All publications imported from WoS & and PM \\
after removal of duplicates & 536 & 2239 & 937 & 3319 \\
After keyword search in titles and abstracts with EndNote & 403 & 1728 & 683 & 1891 \\
Included after manual screening of titles and abstracts & 78 & 120 & 90 & 72 \\
Pharmacognostic studies & 36 & 42 & 21 & 34 \\
Reviews & 16 & 18 & 28 & 7 \\
Publications on adverse effects & 1 & 12 & 34 & 2 \\
Finally included publications & 25 & 48 & 34 & 31 \\
Resulting references $^{c}$ & 29 & 50 & 34
\end{tabular}

${ }^{\mathrm{a}}$ Web of Science [28], ${ }^{\mathrm{b}}$ PubMed [27], ${ }^{\mathrm{c}}$ Reference $=$ one or several clinical, in vivo or in vitro trials of one plant species within one finally included publication (= one line in dditional file 3 ) 

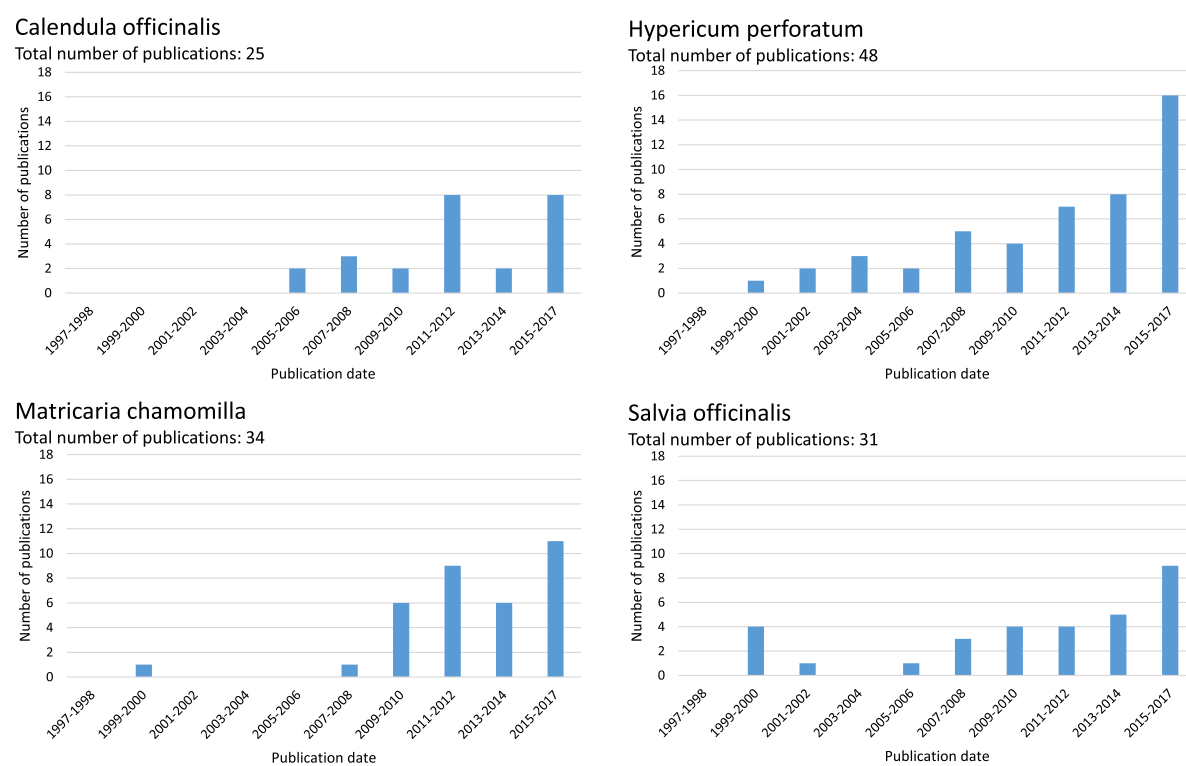

Salvia officinalis

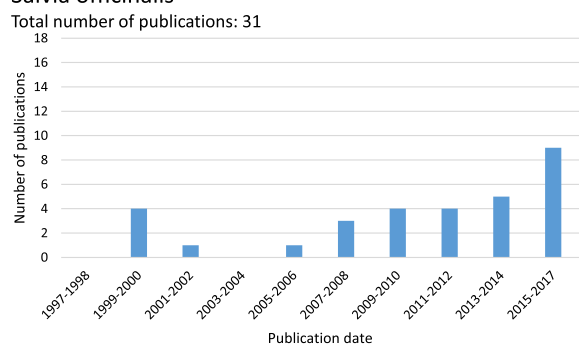

Fig. 2 Distribution of the publication dates of all review included publications sub-divided by plant species

\section{Calendula officinalis}

Total number of references: 29

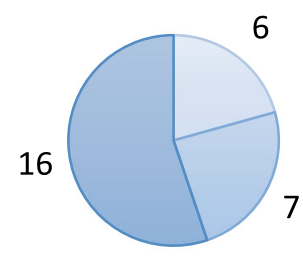

$\square$ clinical $\square$ in vivo $\square$ in vitro

Matricaria chamomilla

Total number of references: 34

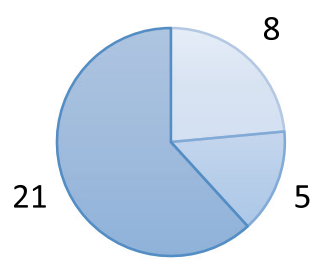

Hypericum perforatum

Total number of references: 50

6

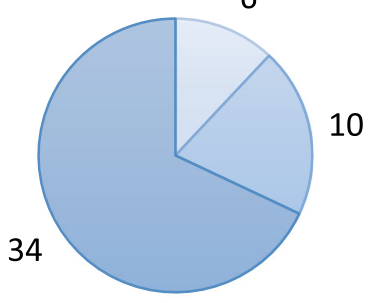

$\square$ clinical $\square$ in vivo $\square$ in vitro

\section{Salvia officinalis}

Total number of references: 32

12

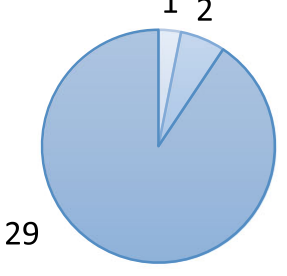

clinical $\square$ in vivo $\square$ in vitro

$\square$ clinical $\square$ in vivo $\square$ in vitro

Fig. 3 Distribution of the experimental design (in vitro, in vivo, clinical) of all review included references sub-divided by plant species 
Table 3 Summary of the amount of references proving (+), giving an unclear result (?), showing no effect (0) or showing the opposite effect (-) for each criterion investigated for each plant species

\begin{tabular}{|c|c|c|c|c|c|c|c|c|c|}
\hline \multirow[t]{2}{*}{ Type of reference } & & \multicolumn{2}{|c|}{ Calendula } & \multicolumn{2}{|c|}{ Hypericum } & \multicolumn{2}{|c|}{ Matricaria } & \multicolumn{2}{|l|}{ Salvia } \\
\hline & & in vitro & $\begin{array}{l}\text { in vivo }+ \\
\text { clinical }\end{array}$ & in vitro & $\begin{array}{l}\text { in vivo }+ \\
\text { clinical }\end{array}$ & in vitro & $\begin{array}{l}\text { in vivo }+ \\
\text { clinical }\end{array}$ & in vitro & $\begin{array}{l}\text { in vivo + } \\
\text { clinical }\end{array}$ \\
\hline \multirow[t]{4}{*}{ Anti-bacterial } & + & $7^{1}$ & & $19^{2}$ & & $11^{3}$ & $1^{4}$ & $20^{5}$ & \\
\hline & $?$ & & & $1^{6}$ & $1^{7}$ & & & & \\
\hline & 0 & & & $1^{8}$ & & $3^{9}$ & & $1^{10}$ & \\
\hline & - & & & & & & & & \\
\hline \multirow[t]{4}{*}{ Synergism with antibiotics/ disinfectants } & + & & & & & $1^{11}$ & & $4^{12}$ & \\
\hline & $?$ & & & & & & & & \\
\hline & 0 & & & & & & & $1^{13}$ & \\
\hline & - & & & & & & & & \\
\hline \multirow[t]{4}{*}{ Anti-fungal } & + & $3^{14}$ & & $10^{15}$ & & $5^{16}$ & & $7^{17}$ & \\
\hline & $?$ & & & & & & & & \\
\hline & 0 & $1^{18}$ & & $4^{19}$ & & $3^{20}$ & & $3^{21}$ & \\
\hline & - & & & & & & & & \\
\hline \multirow[t]{4}{*}{ Anti-biofilm } & + & & & $3^{22}$ & & & & $2^{23}$ & \\
\hline & $?$ & & & & & & & & \\
\hline & 0 & & & & & & & & \\
\hline & - & & & & & & & & \\
\hline \multirow[t]{4}{*}{ Anti-pruritic } & + & & & & $1^{24}$ & & $3^{25}$ & & \\
\hline & $?$ & & & & & & $1^{26}$ & & \\
\hline & 0 & & & & & & & & \\
\hline & - & & & & & & & & \\
\hline \multirow[t]{4}{*}{ Wound-healing } & + & & $8^{27}$ & & $8^{28}$ & & $5^{29}$ & & \\
\hline & $?$ & & & & $1^{30}$ & & & & \\
\hline & 0 & & & & $1^{31}$ & & & & \\
\hline & - & & & & & & & & \\
\hline \multirow[t]{4}{*}{ Fibro-proliferative } & + & $3^{32}$ & $1^{33}$ & & $1^{34}$ & & & & \\
\hline & $?$ & & & $2^{35}$ & & & & & \\
\hline & 0 & $1^{36}$ & & & $3^{37}$ & $2^{38}$ & $1^{39}$ & & \\
\hline & - & & & $2^{40}$ & $1^{41}$ & & & & \\
\hline \multirow[t]{4}{*}{ Fibro-migrative } & + & $2^{42}$ & & $2^{43}$ & & & & & \\
\hline & $?$ & & & & & & & & \\
\hline & 0 & & & & & $1^{44}$ & & & \\
\hline & - & & & $1^{45}$ & & & & & \\
\hline \multirow[t]{4}{*}{ Collagen-enhancing } & + & $1^{46}$ & $2^{47}$ & $2^{48}$ & $4^{49}$ & & $1^{50}$ & & \\
\hline & $?$ & & & & & & & & \\
\hline & 0 & & & & $1^{51}$ & & & & \\
\hline & - & & & & & & & & \\
\hline \multirow[t]{4}{*}{ Pro-angiogenic } & + & $2^{52}$ & $3^{53}$ & & $3^{54}$ & & & & \\
\hline & $?$ & & & & & & & & \\
\hline & 0 & & & & $3^{55}$ & & & & \\
\hline & - & & & $1^{56}$ & & & & & \\
\hline
\end{tabular}


Table 3 Summary of the amount of references proving (+), giving an unclear result (?), showing no effect (0) or showing the opposite effect (-) for each criterion investigated for each plant species (Continued)

\begin{tabular}{|c|c|c|c|c|c|c|c|c|c|}
\hline \multirow[t]{2}{*}{ Type of reference } & & \multicolumn{2}{|c|}{ Calendula } & \multicolumn{2}{|c|}{ Hypericum } & \multicolumn{2}{|c|}{ Matricaria } & \multicolumn{2}{|l|}{ Salvia } \\
\hline & & in vitro & $\begin{array}{l}\text { in vivo }+ \\
\text { clinical }\end{array}$ & in vitro & $\begin{array}{l}\text { in vivo }+ \\
\text { clinical }\end{array}$ & in vitro & $\begin{array}{l}\text { in vivo }+ \\
\text { clinical }\end{array}$ & in vitro & $\begin{array}{l}\text { in vivo + } \\
\text { clinical }\end{array}$ \\
\hline \multirow[t]{4}{*}{ Anti-inflammatory } & + & & $1^{57}$ & $2^{58}$ & $3^{59}$ & & $3^{60}$ & $1^{61}$ & $2^{62}$ \\
\hline & $?$ & & $1^{63}$ & & $1^{64}$ & & & & \\
\hline & 0 & & & & $2^{65}$ & & $1^{66}$ & & \\
\hline & - & $1^{67}$ & & & & & & & \\
\hline \multirow[t]{4}{*}{ Anti-erythematous } & + & & $1^{68}$ & & $2^{69}$ & & $2^{70}$ & & $2^{71}$ \\
\hline & $?$ & & & & & & $1^{72}$ & & \\
\hline & 0 & & & & $2^{73}$ & & & & \\
\hline & - & & & & & & & & \\
\hline \multirow[t]{4}{*}{ Anti-edematous } & + & & & & $3^{74}$ & & $1^{75}$ & & $1^{76}$ \\
\hline & $?$ & & & & & & & & \\
\hline & 0 & & & & $1^{77}$ & & & & \\
\hline & - & & & & & & & & \\
\hline \multirow[t]{4}{*}{ Analgesic } & + & & & & $2^{78}$ & & $2^{79}$ & & \\
\hline & $?$ & & & & & & & & \\
\hline & 0 & & & & & & & & \\
\hline & - & & & & & & & & \\
\hline \multirow[t]{4}{*}{ Beneficial for skin } & + & & $2^{80}$ & & $3^{81}$ & & $1^{82}$ & & \\
\hline & $?$ & & & & & & & & \\
\hline & 0 & & & & $1^{83}$ & & & & \\
\hline & - & & & & & & & & \\
\hline \multirow[t]{4}{*}{ Hypothesis proven } & + & $2^{84}$ & $4^{85}$ & $5^{86}$ & $10^{87}$ & $2^{88}$ & $5^{89}$ & $3^{90}$ & $1^{91}$ \\
\hline & $?$ & & & & & & $1^{92}$ & & \\
\hline & 0 & & & & & $1^{93}$ & $1^{94}$ & & \\
\hline & - & $1^{95}$ & & & & & & & \\
\hline \multirow[t]{4}{*}{ Total } & + & 20 & 22 & 43 & 40 & 19 & 24 & 37 & 6 \\
\hline & $?$ & 0 & 1 & 3 & 3 & 0 & 3 & 0 & 0 \\
\hline & 0 & 2 & 0 & 5 & 14 & 10 & 3 & 3 & 0 \\
\hline & - & 2 & 0 & 4 & 1 & 0 & 0 & 0 & 0 \\
\hline \multicolumn{10}{|c|}{ 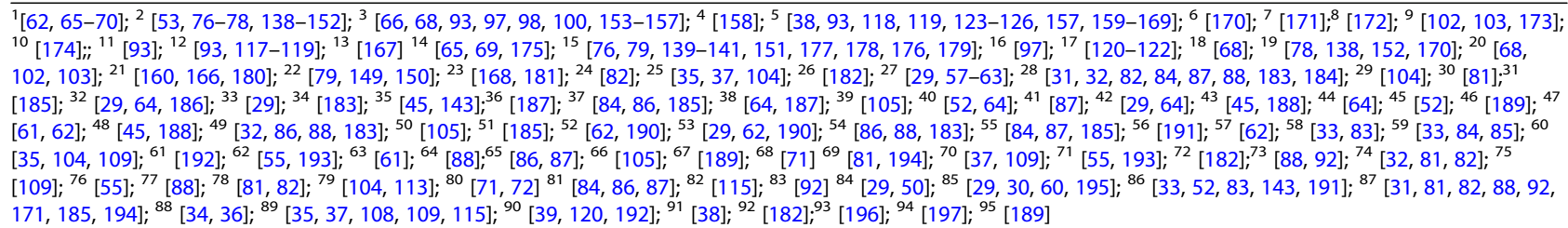 } \\
\hline
\end{tabular}

ability to present alloantigens in a mixed EC lymphocyte reaction and inhibit $\mathrm{T}$ cell proliferation [33]. Chamomile was proven to have a proliferative effect on keratinocytes in vitro [34] and in one study, the topical application of Chamomile essential oil lowered the serum IgG1, histamine and IgE level in atopic dermatitis-like mice [35]. It was also proven that Chamomile can increase the permeability of skin for caffeine and salicylic acid [36] and has good hair care properties in shampoo formulations [37]. Sage was shown to reduce axillary malodor levels when used in a deodorant stick [38] and an in vitro study showed that Sage ethanol extract inhibited NGF-induced neuritic outgrowth in an in vitro study based on a PC12 cell-line [39].

\section{Discussion}

The large number of publications from the last twenty years shows a sound base of evidence-based knowledge about 
these four medicinal plants. Although the number of publications focusing on skin related topics is smaller, the amount is still in a promising range. There is a large number of pharmacognostic publications (a total of 133 for all four plant species) indicating that a broad knowledge on the constituents of the investigated plants is available.

The distribution of publication dates of the publications fitting the topic of this review indicates that there is a trend in investigating the therapeutic potential of these four plants in the context of skin diseases. Interestingly, the amount of publications found on St. John's Wort ( $H$. perforatum) is larger than for the other plants. St. John's Wort has been receiving quite some attention in the last few years as many consumers are already using this medicinal plant for various indications such as depression therapy, urging researchers to investigate on the broad spectrum of effects of this plant [40].

\section{Evaluation of the search strategy}

English or German scientific publications investigating the topical use of Calendula officinalis, Hypericum perforatum, Matricaria chamomilla and Salvia officinalis on dog skin are missing in the last 20 years. Due to this, the goal of this review was to extrapolate therapeutic options of the four medicinal plants for the topical use in dog skin based on studies investigating effects of these plants in other animals' (and human) skin, microorganisms involved in canine skin diseases or closely related to those, cell cultures and other skin in vitro models. In order to avoid source selection bias, four standard textbooks and a survey among experts were used to choose the four most promising plants. It is, however, possible that the chosen books and the use described by the experts in the survey were influenced by each other which would result in a certain sampling bias. Using two different, independent databases and the Mesh Terms function of PubMed reduced the risk of introducing database bias. Also, by limiting the included publications to studies published not before 1997, some important but older research may have not been included in the present review. On the other hand, studies published up to 2017 were included, decreasing this bias.

\section{Varying chemistry of plants}

Interpreting the results of studies investigating effects of plant extracts, it is important to consider that results may vary depending on the type of extract and the extraction method used [41, 42] and the amount of active constituents in the plant material. The amount of active constituents in the plant material itself can be influenced by several environmental factors [43]. Variation between the used plant parts and between subspecies of the plants needs to be considered as well [44, 45]. But the widely varying concentrations of active constituents in traditionally home-made plant-based remedies nevertheless seems to lead to a high level of satisfaction with the outcome of their use by Swiss farmers [46]. A problem is that not all available studies precisely describe the extracts used and therefore a minimum standard on how to report on the constituents should be requested for future studies [47]. To extract studies with comprehensible data and to create comparable units based e.g. on the concentration of raw material in the final preparations is possible but would go beyond the scope of this review.

\section{Multicomponent composition}

The range of pharmacognostic publications found and considered for this review show that there is a broad spectrum of components found within one medicinal plant species, and most of the effects shown cannot be traced back to only one but multiple components of the plants and their extracts. For many effects, the groups of constituents causing them are known. For Chamomile for example, the components showing anti-bacterial activity were identified to be coumarins, flavonoids, phenolic acids, fatty acids and essential oil components [48]. The component bisabolol - which can also be found in Marigold [49] - is known to have anti-irritant and anti-inflammatory properties [37]. Oleanolic acid extracted from Marigold has been proven to be active against Gram-positive and Gram-negative bacteria [50]. A wellknown component of St. John's Wort is hypericin, a substance which is responsible for the photo-sensitizing effects of the plant [51]. Another ingredient found in St. John's Wort, hyperforin, has been shown to have anti-proliferative and anti-migrative effects on fibroblasts [52] and $\alpha$-pinene seems to be one of the components causing the antibacterial activity of St. John's Wort [53]. Also for Sage, a wide range of components has been described. The terpene fraction of this medicinal plant is involved in many of the effects of Sage as it contains $\alpha$ - and $\beta$-thujone, 1,8-cineole, linalool, camphor and a range of other substances [54]. Ursolic acid from Sage has been shown to be one of the components responsible for its anti-inflammatory potential [55].

\section{Calendula officinalis - Marigold}

A well-known traditional indication in Switzerland for the use of Marigold is wound care $[15,56]$. This field of use can be well justified by the results of this review as 8 clinical and in vivo references confirmed this effect [29, 57-63]. There were no references showing any result different than Marigold aiding the healing process. According to the publications assessed in this review, this effect can mainly be attributed to the fibro-proliferative, pro-angiogenic and collagen-enhancing effects of Marigold which were 
confirmed in several clinical, in vivo and in vitro references and also the fibro-migrative effect shown in two in vitro references $[29,64]$.

Seven references investigating the anti-bacterial effects of Marigold were identified, and all of them confirmed Marigold to inhibit the growth of skin-relevant bacteria [62, 65-70]. Even though the anti-bacterial activity of Marigold was not reported to protect against a broad spectrum of bacteria, and even though it may not be the strongest compared to other plant extracts [68], it still adds to Marigold being an interesting option for the treatment of wounds as it combines wound-healing and antibacterial effects.

Three in vitro references also confirmed an antifungal effect and only one in vitro study did not detect any anti-fungal activity of Marigold. This might justify the traditional use of this plant in fungal skin infections [15]. Two references confirmed beneficial effects on the skin such as an increase in skin moisture content, a decrease in the trans-epidermal water loss and an increased firmness of the skin [71, 72]. Such properties might also be interesting for the topical treatment of dogs with CAD as the barrier function of the skin is impaired in these diseases. Again, Marigold could possibly be a treatment fighting secondary infections and strengthening the skin at the same time.

Marigold has also been used traditionally to treat skin inflammation [15]. But the references included in this review show contradictory results and do not provide very strong evidence for the usefulness of Marigold in the treatment of canine skin inflammation $[62,63,72,73]$.

One publication on unwanted adverse effects was found describing contact sensitization to Marigold in humans affecting approximately $2 \%$ of the patients tested [74]. There are some other reports describing this problem to be more or less severe [73, 75] but none of the 13 in vivo and clinical references included in this review reported on any unwanted adverse effects. Also, one of these references conducted an irritant assay of a cream containing $1 \%$ of Marigold extract, demonstrating absence of skin irritation and a low irritability index in rabbits' eyes [60]. Thus, marigold's safety remains controversial.

Based on the strong evidence supporting the woundhealing effect of Marigold, this plant can be considered beneficial in canine wound care. As there are no veterinary drugs e.g. on the Swiss market which support wound healing other than just by disinfecting the wound, Marigold could fill a gap in therapeutic needs by aiding the healing process. The beneficial effects of Marigold on the skin could be used as a component of shampoos or sprays for normal skin care in healthy dogs as well as for dogs with skin problems.

\section{Hypericum perforatum - St. John's Wort}

St. John's Wort is a traditionally used remedy for skin alterations and sores in livestock [56], making it interesting to further investigations on effects and possible applications on dog skin.

The most frequently confirmed skin related effect of St. John's Wort in this review was the antibacterial activity: a total of 21 references investigated this and 20 of them confirmed its antibacterial properties. It inhibited not only Gram-positive but also Gram-negative bacteria while generally showing stronger activity against the Gram-positive bacteria such as S. aureus, S. epidermidis and E. faecalis. St. John's Wort was also proven to be effective against E. coli, $P$. aeruginosa, Proteus mirabilis, Proteus vulgaris, S. epidermidis, several Streptococcus spp., Propionibacterium acnes, several Mycobacterium spp., and Clostridium histiolyticum.

Three references confirmed the activity of St. John's Wort against methicillin-resistant $S$. aureus (MRSA) [76-78]. One reference also confirmed activity against gentamycin-methicillin-resistant S. aureus [76]. Thus, St. John's Wort could be a new promising option for treatment of skin infections with Gram-positive bacteria including possibly MRSP. Another possible field of use for St. John's Wort might be fungal skin infections as out of a total of 14 references investigating this (all of them in vitro), 10 did confirm the antifungal activity of the plant. Six references showed St. John's Wort to be effective against dermatophytes including Trichophyton mentagrophytes, Microsporum gypseum, Microsporum canis and Trichophyton rubrum. There were no references investigating the effect of St. John's Wort on Malassezia pachydermatis but one reference investigated and proved its activity against Malassezia furfur [79]. This shows that St. John's Wort might inhibit the growth of a Malassezia species indicating that it might just as well be active against $M$. pachydermatis. Another factor in support of its anti-yeast activity is the fact that in eight references efficacy against Candida albicans was demonstrated. However C. albicans is infrequently causing infections in dogs but rather in humans but in general Candida spp. are even more resistant to azole antifungal agents than M. pachydermatis [80]. Therefore, it might be worthwhile to confirm efficacy of St John's wort for $M$. pachydermatis as well. St. John's Wort has been proven to be effective in 8 out of 10 references investigating its wound healing potential in in- and excisional wounds as well as experimental thermal burns in rats and in two human clinical trials using St. John's Wort for the treatment of pressure sores and wounds after a cesarean section. The mechanism of the wound healing activity has not been identified as the references included in this review investigating fibroproliferative and fibromigrative effects as well as collagen-enhancing and pro-angiogenic 
properties reported rather mixed results. Still, the references evaluating the wound-healing potential of St. John's Wort indicate that it can be helpful for wound care and as it has a rather broad-spectrum antimicrobial activity, it would qualify especially well for the treatment of infected wounds including bite wounds. Additionally, there were two references investigating and proving topical analgesic effects of St. John's Wort [81, 82], which might present an additional reason to use this plant for wound care.

The results of references considering the anti-inflammatory effect of St. John's Wort do show a tendency towards beneficial effects: while five references confirmed an anti-inflammatory effect [33, 83-85], two could not confirm it $[86,87]$, and one reference did not show a clear result [88]. Two references show significant antierythematous and three references edema reducing effects of St. John's Wort (Table 3). Future studies need to be performed in order to investigate St. John's Wort's anti-inflammatory properties for the treatment of skin disease.

Three references showed further beneficial effects like an increased tensile strength (measured with a tensiometer) of the skin after external St. John's Worts wound treatment, an interesting aspect maybe not only for the treatment of wounds. However, the cellular process behind this finding remains unclear.

Side effects of the use of St. John's Wort preparations have been discussed controversial. Photosensitization was reported for the topical use of St. John's Wort in some studies $[51,89,90]$. On the other hand a recent safety assessment excerted by the Cosmetic Ingredient Review Expert Panel stating that St. John's Wort as used in cosmetic emulsions is rather safe [91]. One reference included in this short review tested a bath oil containing St. John's Wort on human skin and found it to be less irritating than other tested bath oils and sodium lauryl sulfate. It was well tolerated having the same effects on the skin as the negative control, which was distilled water [92].

Considering all these different aspects St. John's Wort may be helpful in the treatment of diseases like dermatophytosis, pyoderma/bacterial overgrowth, otitis externa and infected wounds. Even if clinical research with St. John's Wort formulations in dogs is still missing it might be considered beneficial for topical applications in the treatment of canine skin diseases, maybe also as therapeutical shampoos.

\section{Matricaria chamomilla - Chamomile}

The traditional use of Chamomile for the treatment of skin-related problems in livestock seems to be wellestablished in Switzerland [17] and farmers using it appear to be content with its effects [46]. This indicates that there is a certain potential for Chamomile to be an effective treatment in canine skin disorders as well.
For Chamomile 14 in vitro references evaluating the antibacterial activity of its extracts were found and 11 of them could show an effect. The in vitro references could show inhibitory or even bactericidal effects of Chamomile against a relatively broad range of bacteria including E. coli, P. mirabilis, P. vulgaris, E. faecalis, A. baumanni, Porphyromonas gingivalis, S. aureus, S. epidermidis and other Staphylococci. The antimicrobial activity seemed to be stronger against Gram-positive bacteria and some references only provided evidence for an effect against Gram-positive but not against Gram-negative bacteria. Still, the inhibitory effect of Chamomile on bacteria seems evident and in some references it did present itself as being broad-ranged. One in vitro reference demonstrated Chamomile crude extract to be effective against methicillin-resistant $S$. epidermidis and a synergistic interaction between oxacillin and Chamomile was reported [93]. S. epidermidis is an important member of the canine skin microbiome [94] and is not uncommonly isolated from canine skin and ear infections $[95,96]$. This shows that not only formulations containing Chamomile alone should be considered as new treatments but also formulations combining Chamomile with certain antibiotics may enhance their antimicrobial efficiency. Eight references described the antifungal properties of Chamomile and five of them showed it to be effective against M. canis, M. gypseum, T. mentagrophytes, T. rubrum, T. tonsurans, Aspergillus niger, Aspergillus fumigatus, Candida albicans and each two species of Trichophyton and Aspergillus genus [97-101]. Three references did not show an antifungal effect against $C$. albicans $[68,102,103]$. There were no clinical or in vivo references investigating the antifungal potential of Chamomile. The in vitro references described above demonstrated that extracts of this medicinal plant can be effective against dermatophytes and certain yeasts.

Chamomile was the plant for which the most references investigating anti-pruritic effects could be included. One clinical reference did not show a clear result concerning this effect but two clinical studies on humans $[37,104]$ and one in vivo reference using an AD mice model [35] did report Chamomile and its constituent bisabolol to relieve itching. Even though there were no publications found studying this effect in dogs, it seems likely that Chamomile might have a similar effect on dog skin as on human and mouse skin. Formulations containing Chamomile could thus have an additionally beneficial effect in the treatment of secondary skin infections in atopic dogs, in wound healing and other skin diseases associated with pruritus.

Five publications were included in this review studying the wound-healing effect of Chamomile and sustaining the traditional use of this plant for wound care [56]. 
Chamomile was reported to be effective in the treatment of experimental traumatic tongue ulcers, linear incisional wounds, cutaneous burn wounds, and peristomal skin lesions in human colostomy patients [104-108]. One reference showed a collagen-enhancing effect of Chamomile [105], and three references demonstrated the topical anti-inflammatory effects of Chamomile [35, 104, 109] which might also aid wound healing.

It is not surprising that besides the known and traditionally used systemic anti-inflammatory effect of Chamomile $[15,110]$, it also showed this effect when applied topically. Due to its anti-inflammatory effects it could replace the topical treatment with glucocorticoids not only in otitis externa but also in the management of CAD [111] eliminating the unwanted adverse effects resulting from the steroids [112]. Moreover, two references reported an analgesic effect of topically applied creams containing Chamomile in human patients [104, 113]. Even though there are reports of contact allergy to Chamomile in human patients [114] it is not known if dogs may show similar reactions. Considering the various beneficial effects of this medicinal plant it seems reasonable to investigate its use in dogs despite the unknown risk of provoking adverse reactions.

Due to its broad spectrum of promising scientific results Chamomile seems to be a therapeutic option in dogs suffering from otitis externa, pyotraumatic dermatitis and wounds. These patients might benefit not only from its anti-microbial and anti-inflammatory activity, but also from its analgesic effects.

One reference included in this review added Chamomile hydrophobic extract to dishwashing liquids in order to improve the safety of use. It was found that the extract reduced the transepidermal water loss and improved the skin hydration level in the human probands. Also, the more Chamomile extract was added to the formulations, the less irritant they were [115]. This effect should be considered in the development of dog shampoos for healthy skin and presents another beneficial effect of therapeutic shampoos containing Chamomile.

\section{Salvia officinalis - sage}

Sage leaf is used as a traditional relief of minor skin inflammations and bacterial infections of the skin in humans, and it has been known to have antibacterial properties [116]. The references found in this review showed that Sage is in fact effective against a range of bacteria relevant in skin disease. A total of 21 in vitro references investigated the antibacterial activity of Sage and 20 of them found an antibacterial effect. Fifteen references demonstrated that Sage inhibits the growth of $S$. aureus, seven references showed it to be effective against $E$. coli and six references found Sage to be effective against $P$. aeruginosa. Other bacteria against which
Sage showed an inhibitory effect included S. epidermidis and other Staphylococcus spp., Acinetobacter baumannii, Enterococcus faecalis, Enterococcus hirae, Propionibacterium acnes, Bacteroides vulgatus, Prevotella intermedia, Porphyromonas gingivalis, P. vulgaris, Proteus mirabilis and other Proteus spp. and several Streptococcus spp. and Corynebacterium spp. In addition, methicillin-resistant S. epidermidids was inhibited by Sage as well as MRSA. These observations confirm that extracts of Sage exert broad-spectrum antibacterial activity and are effective even against resistant strains. There were no clinical or in vivo references included in this review which evaluated this effect of Sage on skin. Not only Sage extracts alone, but also combinations of them with antibiotics, seem to be very promising. A total of five references reported synergistic activities between antibiotics and one preservative and extracts of Sage and four of them could demonstrate such effects [93, 117-119]. Different extracts showed synergistic activity together with tetracycline, amoxicillin, chloramphenicol, oxacillin and the preservative propylparaben.

There were ten in vitro references investigating the antifungal activity of Sage. Out of these ten studies, seven reported it to be effective against a range of dermatophytes, yeasts and fungi including T. mentagrophytes [120-122], T. rubrum, T. verrucosum [120], M. gypseum [120-122], M. canis [120, 122], and C. albicans [120-126].

No reports on the potential adverse reactions to the topical application of Sage on dog skin were found. A reference evaluating the effects of different constituents of Sage on human gingival fibroblasts showed no toxicity. Thus, Sage can be considered relatively safe in its use on skin.

Given the promising results of the in vitro references proving the antibacterial effect of Sage, it would be interesting to further investigate the use of Sage in dogs with bacterial skin diseases, ear or wound infections. Sage was demonstrated to have anti-bacterial as well as anti-inflammatory properties. Combining these two properties, Sage seems promising for the treatment of primary or secondary skin infections and in the treatment of otitis externa. Also, the treatment of infected wounds could benefit from the anti-inflammatory component additional to the antibacterial effect. The references proving the antifungal effect of Sage showed that Sage could be effective in the treatment of dermatophytosis. Growth inhibition of C. albicans by Sage indicates a possible additional activity of Sage against $M$. pachydermatis, thus, indicating Sage's possible properties in the treatment of skin and ear infections involving this yeast species [127]. This is especially of interest as treatment failure and rapid recurrences of these infections are common [127]. 


\section{Conclusions}

All plants evaluated in this review possess a certain antibacterial potential and might be useful as a first-line topical treatment for primary and secondary skin infections, in surgical wound care, in wound infections and otitis externa. As antibiotic-resistant bacteria were shown to be susceptible to extracts of these plants, they present a possible new option for the treatment of dogs infected with germs resistant to antimicrobials. The same holds true for the antifungal effects of these four plants described. Hence, they might present an additional option for the treatment of dermatophytosis as well as skin and ear infections involving $M$. pachydermatis and even dermatophytes. Marigold, St. John's Wort and Chamomile were reported to have wound-healing properties and thus, they represent promising candidates in line to fill the therapeutic gap in canine wound-healing agents. St. John's Wort and Chamomile are the most promising species based on the findings of this review regarding anti-inflammatory effects. Thus, these plants may be used in a wide range of canine skin diseases with an inflammatory component. For the treatment of otitis externa and other painful skin conditions the topical treatment with St. John's Wort and Chamomile should be considered.

Chamomile and St. John's Wort have been shown to have beneficial effects even on healthy skin. These two plants could thus be an interesting additive for skin care products like dog shampoos or sprays. Ultimately, each of the plants investigated in this review combines several beneficial effects for the treatment of skin disease which makes them especially interesting due to their specific multicomponent composition. Some studies reported safety concerns in humans for these four medicinal plants. It is unknown if these apply to dogs too. However, as there are also several studies proving the use of these plants to be safe in humans, and as the beneficial effects of these plants are undeniable, these medicinal plants should be taken into account as therapeutic options for skin disorders associated with microbial infections/dysbalance and wound management in dogs, at least in future clinical research.

\section{Additional files}

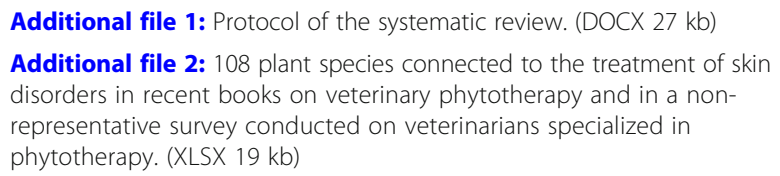

Additional file 3: Assessment of skin associated effects of four medicinal plants in 146 final peer-reviewed references. (XLSX $41 \mathrm{~kb}$ )

\section{Acknowledgements}

We want to thank the 30 specialists of veterinary phytotherapy for assisting us in the selection of the most interesting plant species for the review.

\section{Funding}

This work was done without an extern funding in the frame of a veterinary master thesis at the Vetsuisse Faculty, University of Bern.

\section{Availability of data and materials}

All the data supporting the findings are contained within the manuscript and in the Additional files 1, 2 and 3.

\section{Authors' contributions}

MT designed the review, collected, analysed and interpreted the data and wrote the manuscript. MM1 participated in the design of the study, in the interpretation and discussion of data and coordinated the writing and reviewing of the manuscript. PR contributed her expert-knowledge in canine dermatology and participated in the interpretation and discussion of data. MM2 contributed his expert-knowledge on pharmaceutical biology and participated in the interpretation and discussion of data. HA and MW participated in the design of the study, in the interpretation and discussion of data and in the writing of the manuscript. All authors read and approved the final manuscript.

Ethics approval and consent to participate

Not applicable for this systematic literature review.

\section{Consent for publication}

Not applicable because this manuscript does not contain any individual persons data.

\section{Competing interests}

The authors declare that they have no competing interests.

\section{Publisher's Note}

Springer Nature remains neutral with regard to jurisdictional claims in published maps and institutional affiliations.

\section{Author details}

'Division Veterinary Pharmacology \& Toxicology, Department Clinical Research and Veterinary Public Health, Vetsuisse Faculty, University of Bern, Laenggassstrasse 124, 3012 Bern, Switzerland. ${ }^{2}$ Department of Livestock Sciences, Research Institute of Organic Agriculture (FiBL), Ackerstrasse 113, Postbox 219, 5070 Frick, Switzerland. ${ }^{3}$ Dahlem Centre of Plant Sciences, Institute of Pharmacy, Freie Universität Berlin, Koenigin-Luise-Strasse 2+4, 14195 Berlin, Germany. ${ }^{4}$ Division of Clinical Dermatology, Department of Clinical Veterinary Medicine, Vetsuisse Faculty, University of Bern, Laenggassstrasse 124, 3012 Bern, Switzerland.

Received: 4 May 2018 Accepted: 27 March 2019

Published online: 27 May 2019

\section{References}

1. Kersey KM, Rosales M, Roberts BK. Dermatologic emergencies: identification and treatment. Compend (Yardley, PA). 2013;35(1):E2

2. Hill PB, Lo A, Eden CA, Huntley S, Morey V, Ramsey S, Richardson C, Smith DJ, Sutton C, Taylor MD, et al. Survey of the prevalence, diagnosis and treatment of dermatological conditions in small animals in general practice. Vet Rec. 2006;158(16):533-9.

3. Moriello KA, Coyner K, Paterson S, Mignon B. Diagnosis and treatment of dermatophytosis in dogs and cats.: Clinical Consensus Guidelines of the World Association for Veterinary Dermatology. Vet Dermatol. 2017; 28(3):266-e268.

4. Santoro D, Marsella R, Pucheu-Haston CM, Eisenschenk MN, Nuttall T, Bizikova P. Review: Pathogenesis of canine atopic dermatitis: skin barrier and host-micro-organism interaction. Vet Dermatol. 2015;26(2):84-e25.

5. Beco L, Guaguere E, Lorente Mendez C, Noli C, Nuttall T, Vroom M. Suggested guidelines for using systemic antimicrobials in bacterial skin infections: part 2-- antimicrobial choice, treatment regimens and compliance. Vet Rec. 2013;172(6):156-60.

6. Nazarali A, Singh A, Moens NM, Gatineau M, Sereda C, Fowler D, Kim SE, Kisiel A, Reynolds D, Ringwood BR, et al. Association between methicillinresistant Staphylococcus pseudintermedius carriage and the development of surgical site infections following tibial plateau leveling osteotomy in dogs. J Am Vet Med Assoc. 2015;247(8):909-16. 
7. Arais LR, Barbosa AV, Carvalho CA, Cerqueira AM. Antimicrobial resistance, integron carriage, and gyrA and gyrB mutations in Pseudomonas aeruginosa isolated from dogs with otitis externa and pyoderma in Brazil. Vet Dermatol. 2016;27(2):113-117e131.

8. Beever L, Bond R, Graham PA, Jackson B, Lloyd DH, Loeffler A. Increasing antimicrobial resistance in clinical isolates of Staphylococcus intermedius group bacteria and emergence of MRSP in the UK. Vet Rec. 2015;176(7):172.

9. Soedarmanto I, Kanbar T, Ulbegi-Mohyla H, Hijazin M, Alber J, Lammler C, Akineden O, Weiss R, Moritz A, Zschock M. Genetic relatedness of methicillin-resistant Staphylococcus pseudintermedius (MRSP) isolated from a dog and the dog owner. Res Vet Sci. 2011;91(3):e25-7.

10. Kennedy SA, Stoll LE, Lauder AS. Human and other mammalian bite injuries of the hand: evaluation and management. J Am Acad Orthop Surg. 2015;23(1):47-57.

11. Turk R, Singh A, Weese JS. Prospective surgical site infection surveillance in dogs. Vet Surg. 2015;44(1):2-8.

12. Fortney WD. Implementing a successful senior/geriatric health care program for veterinarians, veterinary technicians, and office managers. Vet Clin North Am Small Anim Pract. 2012;42(4):823-34 viii.

13. Ashcroft GS, Horan MA, Ferguson MW. The effects of ageing on cutaneous wound healing in mammals. J Anat. 1995;187(Pt 1):1-26.

14. Nardoni L, Giovanelli S, Pistelli L, Mugnaini L, Profili G, Pisseri F, Mancianti F. In Vitro Activity of Twenty Commercially Available, PlantDerived Essential Oils against Selected Dermatophyte Species. Nat Prod Commun. 2015;10(8):1473-8.

15. Aichberger L, Graftschafter M, Fritsch F, Gansinger D, Hagmüller W, Hahn-Ramssl I, Hozzank A, Kolar V, Stöger E. Kräuter für Nutz- und Heimtiere: Ratgeber für die Anwendung ausgewählter Heil- und Gewürzplanzen. 2nd ed; 2012.

16. Mayer M, Vogl CR, Amorena M, Hamburger M, Walkenhorst M. Treatment of Organic Livestock with Medicinal Plants: A Systematic Review of European Ethnoveterinary Research. Forschende Komplementarmedizin. 2014;21(6):12.

17. Mayer M, Zbinden M, Vogl CR, Ivemeyer S, Meier B, Amorena M, Maeschli A, Hamburger M, Walkenhorst M. Swiss ethnoveterinary knowledge on medicinal plants - a within-country comparison of Italian speaking regions with north-western German speaking regions. J Ethnobiol Ethnomed. 2017;13:1.

18. Ayrle H, Mevissen M, Kaske M, Nathues H, Gruetzner N, Melzig M, Walkenhorst M. Medicinal plants--prophylactic and therapeutic options for gastrointestinal and respiratory diseases in calves and piglets? A systematic review. BMC Vet Res. 2016:12:89.

19. Liberati A, Altman DG, Tetzlaff J, Mulrow C, Gotzsche PC, loannidis JP, Clarke M, Devereaux PJ, Kleijnen J, Moher D. The PRISMA statement for reporting systematic reviews and meta-analyses of studies that evaluate healthcare interventions: explanation and elaboration. BMJ. 2009;339:b2700.

20. Moher D, Liberati A, Tetzlaff J, Altman DG. Preferred reporting items for systematic reviews and meta-analyses: the PRISMA statement. PLoS Med. 2009;6(7):e1000097.

21. Shea BJ, Grimshaw JM, Wells GA, Boers M, Andersson N, Hamel C, Porter AC, Tugwell P, Moher D, Bouter LM. Development of AMSTAR: a measurement tool to assess the methodological quality of systematic reviews. BMC Med Res Methodol. 2007;7:10.

22. Brendieck-Worm C, Klarer F, Stöger E. Die Haut. In: Heilende Kräuter für Tiere: Pflanzliche Hausmittel für Heim- und Nutztiere. 1st ed; 2015.

23. Reichling J, Frater-Schröder M, Saller R, Fitzi-Rathgen J, Gachnian-Mirtscheva R. Hauterkrankungen 1: Verletzungen (Prellungen, Verstauchungen, Quetschungen), schlecht heilende Wunden und Geschwüre. In: Heilpflanzenkunde für die Veterinärpraxis. 3rd ed; 2016.

24. Reichling J, Frater-Schröder M, Saller R, Fitzi-Rathgen J, Gachnian-Mirtscheva R. Hauterkrankungen 2: Lokale entzündliche Erkrankungen der Haut und Schleimhaut. In: Heilpflanzenkunde für die Veterinärpraxis. 3rd ed; 2016.

25. Wynn SG, Fougère BJ. CHAPTER 20 - Veterinary Herbal Medicine: A Systems-Based Approach. In: Veterinary Herbal Medicine. Saint Louis: Mosby; 2007. p. 291-409.

26. Guidelines for ATCvet classifications. www.whocc.no/atcvet/atcvet/ Accessed 1 Mar 2017.

27. Pubmed.gov. https://www.ncbi.nlm.nih.gov/pubmed/. Accessed 30 Apr 2017.

28. Web of Science TM. https://apps.webofknowledge.com/WOS_GeneralSearch input.do?product=WOS\&search_mode=GeneralSearch\&SID=S2LPa5ic7r5 uqhksQr9\&preferencesSaved=. Accessed 30 Apr 2017.
29. Dinda M, Mazumdar S, Das S, Ganguly D, Dasgupta UB, Dutta A, Jana K, Karmakar P. The Water Fraction of Calendula officinalis Hydroethanol Extract Stimulates In Vitro and In Vivo Proliferation of Dermal Fibroblasts in Wound Healing. Phytother Res. 2016;30(10):1696-707.

30. Fuchs SM, Schliemann-Willers S, Fischer TW, Elsner P. Protective effects of different marigold (Calendula officinalis L.) and rosemary cream preparations against sodium-lauryl-sulfate-induced irritant contact dermatitis. Skin Pharmacol Physiol. 2005;18(4):195-200.

31. Kiyan S, Uyanikgil Y, Altunci YA, Cavusoglu T, Cetin Uyanikgil EO, Karabey F. Investigation of acute effects of Hypericum perforatum (St. John's Wort-Kantaron) treatment in experimental thermal burns and comparison with silver sulfadiazine treatment. Ulus Travma ve Acil Cerrahi Derg. 2015;21(5):323-36.

32. Prisacaru Al, Andritoiu CV, Andriescu C, Havarneanu EC, Popa M, Motoc AG, Sava A. Evaluation of the wound-healing effect of a novel Hypericum perforatum ointment in skin injury. Rom J Morphol Embryol. 2013;54(4):1053-9.

33. Schempp CM, Winghofer B, Ludtke R, Simon-Haarhaus B, Schopf E, Simon JC. Topical application of St John's wort (Hypericum perforatum L.) and of its metabolite hyperforin inhibits the allostimulatory capacity of epidermal cells. Br J Dermatol. 2000;142(5):979-84.

34. Alerico GC, Beckenkamp A, Vignoli-Silva M, Buffon A, von Poser GL. Proliferative effect of plants used for wound healing in Rio Grande do Sul state, Brazil. J Ethnopharmacol. 2015;176:305-10.

35. Lee $\mathrm{SH}$, Heo Y, Kim YC. Effect of German chamomile oil application on alleviating atopic dermatitis-like immune alterations in mice. J Vet Sci. 2010;11(1):35-41.

36. Muhammad F, Wiley J, Riviere JE. Influence of some plant extracts on the transdermal absorption and penetration of marker penetrants. Cutan Ocul Toxicol. 2017;36(1):60-6.

37. Schweiger D, Schoelermann AM, Filbry A, Hamann T, Moser C, Rippke F. Highly efficient and compatible shampoo for use after hair transplant. Clin Cosmet Investig Dermatol. 2015;8:355-60.

38. Shahtalebi MA, Ghanadian M, Farzan A, Shiri N, Shokri D, Fatemi SA. Deodorant effects of a sage extract stick: Antibacterial activity and sensory evaluation of axillary deodorancy. J Res Med Sci. 2013;18(10):833-9.

39. Takano N, Inokuchi Y, Kurachi M. Effects of Ethanol Extracts of Herbal Medicines on Dermatitis in an Atopic Dermatitis Mouse Model. Yakugaku Zasshi J Pharm Soc Jpn. 2011;131(4):581-6.

40. Hammer KD, Birt DF. Evidence for contributions of interactions of constituents to the anti-inflammatory activity of Hypericum perforatum. Crit Rev Food Sci Nutr. 2014;54(6):781-9.

41. Chudnicka A, Matysik G. Research of enzymatic activities of fresh juice and water infusions from dry herbs. J Ethnopharmacol. 2005;99(2):281-6.

42. Avato P, Guglielmi G. Determination of major constituents in St. John's Wort under different extraction conditions. Pharm Biol. 2004;42(1):83-9.

43. Ben Farhat M, Jordan MJ, Chaouech-Hamada R, Landoulsi A, Sotomayor JA. Variations in essential oil, phenolic compounds, and antioxidant activity of tunisian cultivated Salvia officinalis L. J Agric Food Chem. 2009;57(21):10349-56.

44. Barene I, Daberte I, Zvirgzdina L, Iriste V. The complex technology on products of German chamomile. Medicina (Kaunas). 2003;39(Suppl 2):127-31.

45. Dikmen M, Ozturk Y, Sagratini G, Ricciutelli M, Vittori S, Maggi F. Evaluation of the Wound Healing Potentials of Two Subspecies of Hypericum perforatum on Cultured NIH3T3 Fibroblasts. Phytother Res. 2011;25(2):208-14.

46. Disler M, Ivemeyer S, Hamburger M, Vogl CR, Tesic A, Klarer F, Meier B, Walkenhorst M. Ethnoveterinary herbal remedies used by farmers in four north-eastern Swiss cantons (St. Gallen, Thurgau, Appenzell Innerrhoden and Appenzell Ausserrhoden). J Ethnobiol Ethnomed. 2014;10:22.

47. Gagnier JJ, Boon H, Rochon P, Moher D, Barnes J, Bombardier C. Recommendations for reporting randomized controlled trials of herbal interventions: Explanation and elaboration. J Clin Epidemiol. 2006;59(11):1134-49.

48. Moricz AM, Ott PG, Alberti A, Boszormenyi A, Lemberkovics E, Szoke E, Kery A, Mincsovics E. Applicability of preparative overpressured layer chromatography and direct bioautography in search of antibacterial chamomile compounds. J AOAC Int. 2013;96(6):1214-21.

49. Agatonovic-Kustrin S, Babazadeh Ortakand D, Morton DW, Yusof AP. Rapid evaluation and comparison of natural products and antioxidant activity in calendula, feverfew, and German chamomile extracts. J Chromatogr A. 2015;1385:103-10.

50. Zaki A, Ashour A, Mira A, Kishikawa A, Nakagawa T, Zhu Q, Shimizu K. Biological Activities of Oleanolic Acid Derivatives from Calendula officinalis Seeds. Phytoth Res. 2016;30(5):835-41. 
51. Boiy A, Roelandts R, van den Oord J, de Witte PA. Photosensitizing activity of hypericin and hypericin acetate after topical application on normal mouse skin. Br J Dermatol. 2008;158(2):360-9.

52. Fuller J, Muller-Goymann CC. Anti-proliferative and anti-migratory effects of hyperforin in 2D and 3D artificial constructs of human dermal fibroblasts - A new option for hypertrophic scar treatment? Eur J Pharm Biopharm. 2017.

53. Akhbari M, Batooli H, Mozdianfard M. Comparative study of composition and biological activities of SDE prepared essential oils from flowers and fruits of two Hypericum species from central Iran. Nat Prod Res. 2012;26(3):193-202.

54. Arceusz A, Occhipinti A, Capuzzo A, Maffei ME. Comparison of different extraction methods for the determination of alpha- and beta-thujone in sage (Salvia officinalis L.) herbal tea. J Sep Sci. 2013;36(18):3130-4.

55. Baricevic D, Sosa S, Della Loggia R, Tubaro A, Simonovska B, Krasna A, Zupancic A. Topical anti-inflammatory activity of Salvia officinalis L. leaves: the relevance of ursolic acid. J Ethnopharmacol. 2001;75(2-3):125-32

56. Schmid K, Ivemeyer S, Vogl C, Klarer F, Meier B, Hamburger M Walkenhorst M. Traditional Use of Herbal Remedies in Livestock by Farmers in 3 Swiss Cantons (Aargau, Zurich, Schaffhausen). Forsch Komplementarmed. 2012;19(3):125-36.

57. Buzzi M, de Freitas F, de Barros WM. Therapeutic effectiveness of a Calendula officinalis extract in venous leg ulcer healing. J Wound Care. 2016;25(12):732-9.

58. Duran V, Matic M, Jovanovc M, Mimica N, Gajinov Z, Poljacki M, Boza P. Results of the clinical examination of an ointment with marigold (Calendula officinalis) extract in the treatment of venous leg ulcers. Int J Tissue React. 2005;27(3):101-6.

59. Eghdampour F, Jahdie F, Kheyrkhah M, Taghizadeh M, Naghizadeh S, Hagani $\mathrm{H}$. The Impact of Aloe vera and Calendula on Perineal Healing after Episiotomy in Primiparous Women: A Randomized Clinical Trial. J Caring Sci. 2013;2(4):279-86.

60. Menendez AB, Parra AL, Pavon VB, Dominguez CC, Martinez OV, Sardinas IG, Munoz A. Healing effects and irritant assays of a $1 \%$ Calendula officinalis cream. Lat Am J Pharm. 2007;26(6):811-7.

61. Okuma CH, Andrade TA, Caetano GF, Finci LI, Maciel NR, Topan JF, Cefali LC, Polizello AC, Carlo T, Rogerio AP, et al. Development of lamellar gel phase emulsion containing marigold oil (Calendula officinalis) as a potential modern wound dressing. Eur J Pharm Sci. 2015;71:62-72.

62. Parente LM, Lino Junior Rde S, Tresvenzol LM, Vinaud MC, de Paula JR, Paulo NM. Wound Healing and Anti-Inflammatory Effect in Animal Models of Calendula officinalis L Growing in Brazil. Evid Based Complement Alternat Med. 2012;2012:375671.

63. Preethi KC, Kuttan R. Wound healing activity of flower extract of Calendula officinalis. J Basic Clin Physiol Pharmacol. 2009;20(1):73-9.

64. Fronza M, Heinzmann B, Hamburger M, Laufer S, Merfort I. Determination of the wound healing effect of Calendula extracts using the scratch assay with 3 T3 fibroblasts. J Ethnopharmacol. 2009;126(3):463-7.

65. Efstratiou E, Hussain Al, Nigam PS, Moore JE, Ayub MA, Rao JR. Antimicrobial activity of Calendula officinalis petal extracts against fungi, as well as Gramnegative and Gram-positive clinical pathogens. Complement Ther Clin Pract. 2012;18(3):173-6.

66. Garcia AR, Wong LJG, Verde GR, Nino KA. Antimicrobial activity of Thymus vulgaris, Matricaria chamomilla, Croton lechleri, Calendula officinalis L., Julliana adstringens $S c h l$ against periodontophatogen microorganisms. Singapore: World Scientific Publ Co Pte Ltd; 2011.

67. Gumus T, Demirci AS, Sonuc MN, Demirok NT, Tulukcu E, Gulcu M. Investigation of antimicrobial and antioxidant activities of essential oils extracted from medicinal plants. J Food Saf Food Qual. 2016;67(1):17-24.

68. Herman A, Herman AP, Domagalska BW, Mlynarczyk A. Essential Oils and Herbal Extracts as Antimicrobial Agents in Cosmetic Emulsion. Indian J Microbiol. 2013;53(2):232-7.

69. Hussain I, Khader JA, Noor S, Ullah R, Talha M, Badrullah AM. Study on the medicinal plant Calandula officinalis. Afr J Pharm Pharmacol. 2012;6(13):973-8.

70. Szakiel A, Ruszkowski D, Grudniak A, Kurek A, Wolska Kl, Doligalska M, Janiszowska W. Antibacterial and Antiparasitic Activity of Oleanolic Acid and its Glycosides isolated from Marigold (Calendula officinalis). Planta Med. 2008;74(14):1709-15

71. Akhtar N, Zaman SU, Khan BA, Haji M, Khan S, Ahmad M, Rasool F, Mahmood T, Rasul A. Evaluation of various functional skin parameters using a topical cream of Calendula officinalis extract. Afr J Pharm Pharmacol. 2011;5(2):199-206.
72. Akhtar N, Zaman SU, Khan BA, Amir MN, Ebrahimzadeh MA. Calendula extract: effects on mechanical parameters of human skin. Acta Pol Pharm. 2011;68(5):693-701.

73. Paulsen E. Contact sensitization from Compositae-containing herbal remedies and cosmetics. Contact Dermatitis. 2002;47(4):189-98.

74. Reider N, Komericki P, Hausen BM, Fritsch P, Aberer W. The seamy side of natural medicines: contact sensitization to arnica (Arnica montana L.) and marigold (Calendula officinalis L.). Contact Dermatitis. 2001;45(5):269-72.

75. Calapai G, Miroddi M, Minciullo PL, Caputi AP, Gangemi S, Schmidt RJ. Contact dermatitis as an adverse reaction to some topically used European herbal medicinal products - part 1: Achillea millefolium-Curcuma longa. Contact Dermatitis. 2014;71(1):1-12.

76. Mabona U, Viljoen A, Shikanga E, Marston A, Van Vuuren S. Antimicrobial activity of southern African medicinal plants with dermatological relevance: From an ethnopharmacological screening approach, to combination studies and the isolation of a bioactive compound. J Ethnopharmacol. 2013;148(1):45-55.

77. Jesionek W, Moricz AM, Alberti A, Ott PG, Kocsis B, Horvath G, Choma IM. TLC-Direct Bioautography as a Bioassay Guided Method for Investigation of Antibacterial Compounds in Hypericum perforatum L. J AOAC Int. 2015;98(4):1013-20.

78. Oskay M, Sari D. Antimicrobial screening of some Turkish medicinal plants. Pharm Biol. 2007:45(3):176-81.

79. Simonetti G, Tocci N, Valletta A, Brasili E, D'Auria FD, Idoux A, Pasqua G. In vitro antifungal activity of extracts obtained from Hypericum perforatum adventitious roots cultured in a mist bioreactor against planktonic cells and biofilm of Malassezia furfur. Nat Prod Res. 2016;30(5):544-50.

80. Brito EHS, Fontenelle ROS, Brilhante RSN, Cordeiro RA, Soares Júnior FA, Monteiro AJ, Sidrim JJC, Rocha MFG. Phenotypic characterization and in vitro antifungal sensitivity of Candida spp. and Malassezia pachydermatis strains from dogs. Vet J. 2007;174(1):147-53.

81. Hajhashemi M, Ghanbari Z, Movahedi M, Rafieian M, Keivani A, Haghollahi F. The effect of Achillea millefolium and Hypericum perforatum ointments on episiotomy wound healing in primiparous women. J Matern Fetal Neonatal Med. 2017:31:1-7.

82. Samadi S, Khadivzadeh T, Emami A, Moosavi NS, Tafaghodi M, Behnam HR. The Effect of Hypericum perforatum on the Wound Healing and Scar of Cesarean. J Altern Complement Med. 2010;16(1):113-7.

83. Orhan IE, Kartal M, Gulpinar AR, Yetkin G, Orlikova B, Diederich M, Tasdemir D. Inhibitory effect of St. Johns Wort oil macerates on TNFalpha-induced NF-kappaB activation and their fatty acid composition. J Ethnopharmacol. 2014;155(2):1086-92.

84. Suntar IP, Akkol EK, Yilmazer D, Baykal T, Kirmizibekmez H, Alper M, Yesilada E. Investigations on the in vivo wound healing potential of Hypericum perforatum L. J Ethnopharmacol. 2010;127(2):468-77.

85. Sosa S, Pace R, Bornancin A, Morazzoni P, Riva A, Tubaro A, Della Loggia R. Topical anti-inflammatory activity of extracts and compounds from Hypericum perforatum L. J Pharm Pharmacol. 2007;59(5):703-9.

86. Altiparmak M, Eskitascioglu T. Comparison of Systemic and Topical Hypericum perforatum on Diabetic Surgical Wounds. J Invest Surg. 2017;31:1-9.

87. Farsak M, Ozdagli G, Ozmus D, Comelekoglu U, Yalin S, Bozdogan Arpaci R, Gen R, Kanik A, Umit Talas D. Effects of Hypericum perforatum on an Experimentally Induced Diabetic Wound in a Rat Model. Wounds. 2017;29(2):E10-e17.

88. Han MC, Durmus AS, Sagliyan A, Gunay C, Ozkaraca M, Kandemir FM, Comakli S, Oztopalan DF. Effects of Nigella sativa and Hypericum perforatum on wound healing. Turk J Vet Anim Sci. 2017;41(1):99-105.

89. Schempp CM, Ludtke R, Winghofer B, Simon JC. Effect of topical application of Hypericum perforatum extract (St. John's wort) on skin sensitivity to solar simulated radiation. Photodermatol Photoimmunol Photomed. 2000;16(3):125-8.

90. Bernd A, Simon S, Ramirez Bosca A, Kippenberger S, Diaz Alperi J, Miquel J, Villalba Garcia JF, Pamies Mira D, Kaufmann R. Phototoxic effects of Hypericum extract in cultures of human keratinocytes compared with those of psoralen. Photochem Photobiol. 1999;69(2):218-21.

91. Becker LC, Bergfeld WF, Belsito DV, Hill RA, Klaassen CD, Liebler DC, Marks JG, Shank RC, Slaga TJ, Snyder PW, et al. Amended Safety Assessment of Hypericum perforatum-Derived Ingredients as Used in Cosmetics. Int J Toxicol. 2014;33:5S-23S.

92. Reuter J, Huyke C, Scheuvens H, Ploch M, Neumann K, Jakob T, Schempp CM. Skin Tolerance of a New Bath Oil Containing St. John's Wort Extract. Skin Pharmacol Physiol. 2008;21(6):306-11. 
93. Chovanova R, Mikulasova M, Vaverkova S. In Vitro Antibacterial and Antibiotic Resistance Modifying Effect of Bioactive Plant Extracts on Methicillin-Resistant Staphylococcus epidermidis. Int J microbiol. 2013;2013: 760969.

94. Torres S, Clayton JB, Danzeisen JL, Ward T, Huang H, Knights D, Johnson TJ. Diverse bacterial communities exist on canine skin and are impacted by cohabitation and time. PeerJ. 2017;5:e3075

95. Kern A, Perreten V. Clinical and molecular features of methicillin-resistant, coagulase-negative staphylococci of pets and horses. J Antimicrob Chemother. 2013;68(6):1256-66.

96. Penna B, Varges R, Medeiros L, Martins GM, Martins RR, Lilenbaum W. Species distribution and antimicrobial susceptibility of staphylococci isolated from canine otitis externa. Vet Dermatol. 2010;21(3):292-6.

97. Abdoul-Latif FM, Mohamed N, Edou P, Ali AA, Djama SO, Obame LC, Bassole $\mathrm{HN}$, Dicko MH. Antimicrobial and antioxidant activities of essential oil and methanol extract of Matricaria chamomilla L. from Djibouti. J Med Plants Res. 2011;5(9):1512-7.

98. Cvetanovic A, Svarc-Gajic J, Zekovic Z, Savic S, Vulic J, Maskovic P, Cetkovic G. Comparative analysis of antioxidant, antimicrobiological and cytotoxic activities of native and fermented chamomile ligulate flower extracts. Planta. 2015;242(3):721-32.

99. Jamalian A, Shams-Ghahfarokhi M, Jaimand K, Pashootan N, Amani A, Razzaghi-Abyaneh M. Chemical composition and antifungal activity of Matricaria recutita flower essential oil against medically important dermatophytes and soil-borne pathogens. J Mycol Med. 2012;22(4): 308-15.

100. Satyal P, Shrestha S, Setzer WN. Composition and bioactivities of an (E)beta-Farnesene Chemotype of chamomile (Matricaria chamomilla) essential oil from Nepal. Nat Prod Commun. 2015;10(8):1453-7.

101. Thombare S, Mukundan U. Control of M-furfur using plant essential oil. J Pure Appl Microbiol. 2012;6(4):1955-8.

102. Liakos I, Rizzello L, Scurr DJ, Pompa PP, Bayer IS, Athanassiou A. All-natural composite wound dressing films of essential oils encapsulated in sodium alginate with antimicrobial properties. Int J Pharm. 2014;463(2):137-45.

103. Mekonnen A, Yitayew B, Tesema A, Taddese S. In vitro antimicrobial activity of essential oil of Thymus schimperi, Matricaria chamomilla, Eucalyptus globulus, and Rosmarinus officinalis. International journal of microbiology. 2016;2016:9545693.

104. Charousaei F, Dabirian A, Mojab F. Using chamomile solution or a $1 \%$ topical hydrocortisone ointment in the management of peristomal skin lesions in colostomy patients: results of a controlled clinical study. Ostomy Wound Manage. 2011;57(5):28-36.

105. Duarte CM, Quirino MR, Patrocinio MC, Anbinder AL. Effects of Chamomilla recutita (L.) on oral wound healing in rats. Med Oral Patol Oral Cir Bucal. 2011;16(6):e716-21.

106. Jarrahi M. An experimental study of the effects of Matricaria chamomilla extract on cutaneous burn wound healing in albino rats. Nat Prod Res. 2008;22(5):423-8.

107. Jarrahi M, Vafaei AA, Taherian AA, Miladi H, Pour AR. Evaluation of topical Matricaria chamomilla extract activity on linear incisional wound healing in albino rats. Nat Prod Res. 2010;24(8):697-702.

108. Martins MD, Marques MM, Bussadori SK, Martins MA, Pavesi VC, MesquitaFerrari RA, Fernandes KP. Comparative analysis between Chamomilla recutita and corticosteroids on wound healing. An in vitro and in vivo study. Phytother Res. 2009;23(2):274-8.

109. Arsic I, Tadic V, Vlaovic D, Homsek I, Vesic S, Isailovic G, Vuleta G. Preparation of novel Apigenin-enriched, liposomal and non-liposomal, Antiinflammatory topical formulations as substitutes for corticosteroid therapy. Phytother Res. 2011;25(2):228-33.

110. Miraj S, Alesaeidi S. A systematic review study of therapeutic effects of Matricaria recuitta chamomile (chamomile). Electron Physician. 2016;8(9):3024-31.

111. Saridomichelakis MN, Olivry T. An update on the treatment of canine atopic dermatitis. Vet J. 2016;207:29-37.

112. Paterson S. Topical ear treatment - options, indications and limitations of current therapy. J Small Anim Pract. 2016;57(12):668-78.

113. Aradmehr M, Azhari S, Ahmadi S, Azmoude E. The effect of chamomile cream on episiotomy pain in Primiparous women: a randomized clinical trial. J Caring Sci. 2017;6(1):19-28.

114. Jovanovic M, Poljacki M, Duran V, Vujanovic L, Sente R, Stojanovic S. Contact allergy to Compositae plants in patients with atopic dermatitis. Med Pregl. 2004:57(5-6):209-18
115. Wasilewski T, Seweryn A, Krajewski M. Improvement in the safety of use of hand dishwashing liquids through the addition of hydrophobic plant extracts. J Surfactant Deterg. 2016;19(6):1315-26.

116. Dawid-Pać R. Medicinal plants used in treatment of inflammatory skin diseases. Postepy Dermatol Alergol. 2013;30(3):170-7.

117. Chovanova R, Mezovska J, Vaverkova S, Mikulasova M. The inhibition the Tet $(K)$ efflux pump of tetracycline resistant Staphylococcus epidermidis by essential oils from three Salvia species. Lett Appl Microbiol. 2015;61(1):58-62.

118. Patrone V, Campana R, Vittoria E, Baffone W. In vitro synergistic activities of essential oils and surfactants in combination with cosmetic preservatives against Pseudomonas aeruginosa and Staphylococcus aureus. Curr Microbiol. 2010;60(4):237-41.

119. Stefanovic OD, Stanojevic DD, Comic LR. Synergistic antibacterial activity of Salvia officinalis and Cichorium intybus extracts and antibiotics. Acta Pol Pharm. 2012;69(3):457-63.

120. Abu-Darwish MS, Cabral C, Ferreira IV, Goncalves MJ, Cavaleiro C, Cruz MT, Al-bdour TH, Salgueiro L. Essential oil of common sage (Salvia officinalis L.) from Jordan: assessment of safety in mammalian cells and its antifungal and anti-inflammatory potential. Biomed Res Int. 2013;2013:538940.

121. Tan N, Satana D, Sen B, Tan E, Altan HB, Demirci B, Uzun M. Antimycobacterial and antifungal activities of selected four Salvia species. Rec Nat Prod. 2016;10(5):593-603.

122. Tullio V, Nostro A, Mandras N, Dugo P, Banche G, Cannatelli MA, Cuffini AM, Alonzo V, Carlone NA. Antifungal activity of essential oils against filamentous fungi determined by broth microdilution and vapour contact methods. J Appl Microbiol. 2007;102(6):1544-50.

123. Benedec D, Hanganu D, Oniga I, Tiperciuc B, Olah NK, Raita O, Bischin C, Silaghi-Dumitrescu R, Vlase L. Assessment of rosmarinic acid content in six Lamiaceae species extracts and their antioxidant and antimicrobial potential. Pak J Pharm Sci. 2015;28(6 Suppl):2297-303.

124. Bouaziz M, Yangui T, Sayadi S, Dhouib A. Disinfectant properties of essential oils from Salvia officinalis L. cultivated in Tunisia. Food Chem Toxicol. 2009:47(11):2755-60.

125. Hammer KA, Carson CF, Riley TV. Antimicrobial activity of essential oils and other plant extracts. J Appl Microbiol. 1999;86(6):985-90.

126. Warnke PH, Becker ST, Podschun R, Sivananthan S, Springer IN, Russo PA, Wiltfang J, Fickenscher $\mathrm{H}$, Sherry $\mathrm{E}$. The battle against multi-resistant strains: renaissance of antimicrobial essential oils as a promising force to fight hospital-acquired infections. J Craniomaxillo fac Surg. 2009;37(7):392-7.

127. Sihelska Z, Vaczi P, Conkova E. Species composition of Malassezia yeasts in dogs in Slovakia. Berl Munch Tierarztl Wochenschr. 2016;129(7-8):351-4.

128. Holm BR, Rest JR, Seewald W. A prospective study of the clinical findings, treatment and histopathology of 44 cases of pyotraumatic dermatitis. Vet Dermatol. 2004;15(6):369-76.

129. Lowenstein C. Pyoderma in dogs. Tierarztliche Praxis Ausgabe K Kleintiere Heimtiere. 2011;39(6):405-17 quiz 418.

130. Hensel P, Santoro D, Favrot C, Hill P, Griffin C. Canine atopic dermatitis: detailed guidelines for diagnosis and allergen identification. BMC Vet Res. 2015;11:196.

131. Bizikova P, Santoro D, Marsella R, Nuttall T, Eisenschenk MN, Pucheu-Haston CM. Review: clinical and histological manifestations of canine atopic dermatitis. Vet Dermatol. 2015;26(2):79-e24.

132. Boynosky NA, Stokking LB. Retrospective evaluation of canine dermatitis secondary to Corynebacterium spp. J Am Anim Hosp Assoc. 2015;51(6):372-9.

133. Chiavassa E, Tizzani $P$, Peano A. In vitro antifungal susceptibility of Malassezia pachydermatis strains isolated from dogs with chronic and acute otitis externa. Mycopathologia. 2014;178(3-4):315-9.

134. Foster A, Morandi F, May E. Prevalence of ear disease in dogs undergoing multidetector thin-slice computed tomography of the head. Vet Radiol Ultrasound. 2015:56(1):18-24.

135. Goodale EC, Outerbridge CA, White SD. Aspergillus otitis in small animals--a retrospective study of 17 cases. Vet Dermatol. 2016;27(1):3-e2.

136. Bismarck D, Schneider MM, E. Antibakterielle in-vitro Wirksamkeit ätherischer Öle gegen veterinärmedizinisch relevante Keime klinischer Isolate von Hunden, Katzen und Pferden. Complement Med Res. 2017;24:153-63.

137. Windahl U, Bengtsson B, Nyman AK, Holst BS. The distribution of pathogens and their antimicrobial susceptibility patterns among canine surgical wound infections in Sweden in relation to different risk factors. Acta Vet Scand. 2015;57:11.

138. Avato P, Raffo F, Guglielmi G, Vitali C, Rosato A. Extracts from St John's wort and their antimicrobial activity. Phytother Res. 2004;18(3):230-2. 
139. Borchardt JR, Wyse DL, Sheaffer CC, Kauppi KL, Fulcher RG, Ehlke NJ, Biesboer DD, Bey RF. Antimicrobial activity of native and naturalized plants of Minnesota and Wisconsin. J Med Plants Res. 2008;2(5):98-110.

140. Cecchini C, Cresci A, Coman MM, Ricciutelli M, Sagratini G, Vittori S, Lucarini D, Maggi F. Antimicrobial activity of seven Hypericum entities from Central Italy. Planta Med. 2007;73(6):564-6.

141. Conforti F, Statti GA, Tundis R, Bianchi A, Agrimonti C, Sacchetti G, Andreotti E, Menichini F, Poli F. Comparative chemical composition and variability of biological activity of methanolic extracts from Hypericum perforatum L. Nat Prod Res. 2005;19(3):295-303.

142. Ghasemi Pirbalouti A, Fatahi-Vanani M, Craker L, Shirmardi H. Chemical composition and bioactivity of essential oils of Hypericum helianthemoides, Hypericum perforatum and Hypericum scabrum. Pharm Biol. 2014;52(2):175-81

143. Gunes S, Tihminlioglu F. Hypericum perforatum incorporated chitosan films as potential bioactive wound dressing material. Int J Biol Macromol. 2017.

144. Keles O, Ak S, Bakirel T, Alpinar K. Screening of some Turkish plants for antibacterial activity. Turk J Vet Anim Sci. 2001;25(4):559-65

145. Males Z, Brantner AH, Sovic K, Pilepic KH, Plazibat M. Comparative phytochemical and antimicrobial investigations of Hypericum perforatum $L$ subsp. perforatum and H. perforatum subsp. angustifolium (DC.) Gaudin. Acta Pharm. 2006;56(3):359-67.

146. Mortensen T, Shen S, Shen F, Walsh MK, Sims RC, Miller CD. Investigating the effectiveness of St John's wort herb as an antimicrobial agent against mycobacteria. Phytother Res. 2012;26(9):1327-33.

147. Nikolic GS, Zlatkovic SZ. Assaying the variation in secondary metabolites of St. John's wort for its better use as an antibiotic. J Med Plants Res. 2010;4(3):211-24.

148. Okmen AS. Antioxidant and antibacterial activities of different plants extracts against staphylococcus aureus isolated from soccer player's shoes and knowledge and applications about foot hygiene of the soccer players Afr J Tradit Complement Alt M. 2015;12(3):143-9.

149. Schiavone BI, Rosato A, Marilena M, Gibbons S, Bombardelli E, Verotta L, Franchini C, Corbo F. Biological evaluation of hyperforin and its hydrogenated analogue on bacterial growth and biofilm production. J Nat Prod. 2013;76(9):1819-23.

150. Suntar I, Oyardi O, Akkol EK, Ozcelik B. Antimicrobial effect of the extracts from Hypericum perforatum against oral bacteria and biofilm formation. Pharm Biol. 2016;54(6):1065-70

151. Vajs V, Vugdelija S, Trifunovic S, Karadzic I, Juranic N, Macura S, Milosavljevic S. Further degradation product of hyperforin from Hypericum perforatum (St. John's wort). Fitoterapia. 2003;74(5):439-44

152. Weseler A, Saller R, Reichling J. Comparative investigation of the antimicrobial activity of PADMA 28 and selected European herbal drugs. Forsch Komplementmed Klass Naturheilkd. 2002:9(6):346-51.

153. Jesionek W, Moricz AM, Ott PG, Kocsis B, Horvath G, Choma IM. TLC-direct bioautography and LC/MS as complementary methods in identification of antibacterial agents in plant tinctures from the Asteraceae Family. J AOAC Int. 2015;98(4):857-61.

154. Mekinic IG, Skroza D, Ljubenkov I, Krstulovic L, Mozina SS, Katalinic V. Phenolic acids profile, antioxidant and antibacterial activity of chamomile, common yarrow and immortelle (Asteraceae). Nat Prod Commun. 2014;9(12):1745-8.

155. Munir N, lqbal AS, Altaf I, Bashir R, Sharif N, Saleem F, Naz S. Evaluation of antioxidant and antimicrobial potential of two endangered plant species ATROPA belladonna and MATRICARIA CHAMOMILLA. Afr J Tradit Complement Alt M. 2014;11(5):111-7.

156. Silva NC, Barbosa L, Seito LN, Fernandes A Jr. Antimicrobial activity and phytochemical analysis of crude extracts and essential oils from medicinal plants. Nat Prod Res. 2012;26(16):1510-4.

157. Sokovic M, Glamoclija J, Marin PD, Brkic D, van Griensven LJ. Antibacterial effects of the essential oils of commonly consumed medicinal herbs using an in vitro model. Molecules. 2010;15(11):7532-46.

158. Darvishi Khezri H, Haidari Gorji MA, Morad A, Gorji H. Comparison of the antibacterial effects of matrica \& Persica and chlorhexidine gluconate mouthwashes in mechanically ventilated ICU patients: a double blind randomized clinical trial. Rev Chilena Infectol. 2013;30(4):361-73.

159. Abu-Darwish MS, Al-Ramamneh EA, Kyslychenko VS, Karpiuk UV. The antimicrobial activity of essential oils and extracts of some medicinal plants grown in ash-shoubak region - south of Jordan. Pak J Pharm Sci. 2012;25(1):239-46.
160. Carvalho JCT, Vignoli W, de Souza GHB, Ujikawa K, Neto JJ. Antimicrobial activity of essential oils from plants used in Brazilian popular medicine. In: Martino V, Caffini N, Lappa A, Schilcher H, Phillipson JD, Tchernitchin A, Debenedetti S, Acevedo C, editors. Second World Congress on Medicinal and Aromatic Plants for Human Welfare Wocmap-2: Pharmacognosy, Pharmacology, Phytomedicines, Toxicology. edn. Leuven: International Society Horticultural Science; 1999. p. 77-81.

161. Evrendilek GA. Empirical prediction and validation of antibacterial inhibitory effects of various plant essential oils on common pathogenic bacteria. Int J Food Microbiol. 2015;202:35-41.

162. Koga T, Hirota N, Takumi K. Bactericidal activities of essential oils of basil and sage against a range of bacteria and the effect of these essential oils on Vibrio parahaemolyticus. Microbiol Res. 1999;154(3):267-73.

163. Kozlowska M, Laudy AE, Przybyl J, Ziarno M, Majewska E. Chemical composition and antibacterial activity of some medicinal plants from LAMIACEAE FAMILY. Acta Pol Pharm. 2015;72(4):757-67.

164. Leelapornpisid P, Chansakao S, Ittiwittayawat T, Pruksakorn S. Antimicrobial activity of herbal extracts on Staphylococcus aureus and Propionibacterium acnes. In: Brovelli E, Chansakaow S, Farias D, Hongratanaworakit T, Omary MB, Vejabhikul S, editors. WOCMAP III: Quality, Efficacy, Safety, Processing and Trade in MAPs. Leuven: International Society Horticultural Science; 2005. p. 97-104.

165. Stagos D, Portesis N, Spanou C, Mossialos D, Aligiannis N, Chaita E, Panagoulis C, Reri E, Skaltsounis L, Tsatsakis AM, et al. Correlation of total polyphenolic content with antioxidant and antibacterial activity of 24 extracts from Greek domestic Lamiaceae species. Food Chem Toxicol. 2012;50(11):4115-24.

166. Weckesser S, Engel K, Simon-Haarhaus B, Wittmer A, Pelz K, Schempp CM. Screening of plant extracts for antimicrobial activity against bacteria and yeasts with dermatological relevance. Phytomedicine. 2007;14(7-8):508-16.

167. Mehdizadeh T, Hashemzadeh MS, Nazarizadeh A, Neyriz-Naghadehi M, Tat M, Ghalavand M, Dorostkar R. Chemical composition and antibacterial properties of Ocimum basilicum, Salvia officinalis and Trachyspermum ammi essential oils alone and in combination with nisin. Res J Pharmacogn. 2016;3(4):51-8.

168. Raffaella C, Casettari L, Fagioli L, Cespi M, Bonacucina G, Baffone W. Activity of essential oil-based microemulsions against Staphylococcus aureus biofilms developed on stainless steel surface in different culture media and growth conditions. Int J Food Microbiol. 2017;241:132-40.

169. Snowden R, Harrington H, Morrill K, Jeane L, Garrity J, Orian M, Lopez E, Rezaie S, Hassberger K, Familoni D, et al. A comparison of the antiStaphylococcus aureus activity of extracts from commonly used medicinal plants. J Altern Complement Med. 2014;20(5):375-82.

170. Orhan IE, Kartal M, Gulpinar AR, Cos P, Matheeussen A, Maes L, Tasdemir D. Assessment of antimicrobial and antiprotozoal activity of the olive oil macerate samples of Hypericum perforatum and their LC-DAD-MS analyses. Food Chem. 2013;138(2-3):870-5.

171. Schempp CA, Windeck T, Hezel S, Simon JC. Topical treatment of atopic dermatitis with St. John's wort cream - a randomized, placebo controlled, double blind half-side comparison. Phytomedicine. 2003;10:31-7.

172. Dastagir G, Ahmed R, Shereen S. Elemental, nutritional, phytochemical and biological evaluation of Hypericum perforatum Linn. Pak J Pharm Sci. 2016:29(2):547-55.

173. Sakkas H, Gousia P, Economou V, Sakkas V, Petsios S, Papadopoulou C. In vitro antimicrobial activity of five essential oils on multidrug resistant gramnegative clinical isolates. J Intercult Ethnopharmacol. 2016;5(3):212-8.

174. Nascimento GGF, Locatelli J, Freitas PC, Silva GL. Antibacterial activity of plant extracts and phytochemicals on antibiotic-resistant bacteria. Braz J Microbiol. 2000:31(4):247-56.

175. Gazim ZC, Rezende CM, Fraga SR, Svidzinski TI, Cortez DA. Antifungal activity of the essential oil from Calendula officinalis L. (asteraceae) growing in Brazil. Braz J Microbiol. 2008;39(1):61-3.

176. Sytar O, Svediene J, Loziene K, Paskevicius A, Kosyan A, Taran N. Antifungal properties of hypericin, hypericin tetrasulphonic acid and fagopyrin on pathogenic fungi and spoilage yeasts. Pharm Biol. 2016; 54(12):3121-5.

177. Tocci N, D'Auria FD, Simonetti G, Panella S, Palamara AT, Debrassi A, Rodrigues CA, Filho VC, Sciubba F, Pasqua G. Bioassay-guided fractionation of extracts from Hypericum perforatum in vitro roots treated with carboxymethylchitosans and determination of antifungal activity against human fungal pathogens. Plant physiology and biochemistry : PPB. 2013;70:342-7.

178. Tocci N, D'Auria FD, Simonetti G, Panella S, Palamara AT, Pasqua G. A threestep culture system to increase the xanthone production and antifungal 
activity of Hypericum perforatum subsp. angustifolium in vitro roots. Plant Physiol Biochem. 2012;57:54-8.

179. Tocci N, Simonetti G, D'Auria FD, Panella S, Palamara AT, Valletta A, Pasqua G. Root cultures of Hypericum perforatum subsp. angustifolium elicited with chitosan and production of xanthone-rich extracts with antifungal activity. Appl Microbiol Biotechnol. 2011;91(4):977-87.

180. Martins N, Barros L, Santos-Buelga C, Henriques M, Silva S, Ferreira IC. Evaluation of bioactive properties and phenolic compounds in different extracts prepared from Salvia officinalis L. Food Chem. 2015;170:378-85.

181. Stojanovic-Radic Z, Pejcic M, Stojanovic N, Sharifi-Rad J, Stankovic N. Potential of Ocimum basilicum L. and Salvia officinalis L. essential oils against biofilms of $P$. aeruginosa clinical isolates. Cell Mol Biol (Noisy-leGrand). 2016;62(9):27-33.

182. Patzelt-Wenczler R, Ponce-Poschl E. Proof of efficacy of Kamillosan(R) cream in atopic eczema. Eur J Med Res. 2000;5(4):171-5.

183. Yadollah-Damavandi S, Chavoshi-Nejad M, Jangholi E, Nekouyian N, Hosseini S, Seifaee A, Rafiee S, Karimi H, Ashkani-Esfahani S, Parsa Y, et al. Topical Hypericum perforatum improves tissue regeneration in full-thickness excisional wounds in diabetic rat model. Evid Based Complement Altern Med. 2015;2015(245328):4. https://doi.org/10.1155/2015/245328.

184. Yucel A, Kan Y, Yesilada E, Akin O. Effect of St.John's wort (Hypericum perforatum) oily extract for the care and treatment of pressure sores; a case report. J Ethnopharmacol. 2017;196:236-41.

185. Castro FC, Magre A, Cherpinski R, Zelante PM, Neves LM, Esquisatto MA, Mendonca FA, Santos GM. Effects of microcurrent application alone or in combination with topical Hypericum perforatum L. and Arnica Montana L. on surgically induced wound healing in Wistar rats. Homeopathy. 2012;101(3):147-53.

186. Dinda M, Dasgupta U, Singh N, Bhattacharyya D, Karmakar P. PI3K-mediated proliferation of fibroblasts by Calendula officinalis tincture: implication in wound healing. Phytother Res. 2015;29(4):607-16.

187. Wyganowska-Swiatkowska M, Urbaniak P, Szkaradkiewicz A, Jankun J, Kotwicka M. Effects of chlorhexidine, essential oils and herbal medicines (Salvia, chamomile, Calendula) on human fibroblast in vitro. Cent Eur J Immunol. 2016;41(2):125-31.

188. Ozturk N, Korkmaz S, Ozturk Y. Wound-healing activity of St. John's wort (Hypericum perforatum L.) on chicken embryonic fibroblasts. J Ethnopharmacol. 2007;111(1):33-9.

189. Nicolaus C, Junghanns S, Hartmann A, Murillo R, Ganzera M, Merfort I. In vitro studies to evaluate the wound healing properties of Calendula officinalis extracts. J Ethnopharmacol. 2017;196:94-103.

190. Parente LM, Andrade MA, Brito LA, Moura VM, Miguel MP, Lino-Junior Rde S, Tresvenzol LF, Paula JR, Paulo NM. Angiogenic activity of Calendula officinalis flowers L. in rats. Acta Cir Bras. 2011;26(1):19-24.

191. Kiyan HT, Demirci B, Baser KHC, Demirci F. The in vivo evaluation of antiangiogenic effects of Hypericum essential oils using the chorioallantoic membrane assay. Pharm Biol. 2014;52(1):44-50.

192. Ehrnhofer-Ressler MM, Fricke K, Pignitter M, Walker JM, Walker J, Rychlik M, Somoza V. Identification of 1,8-cineole, borneol, camphor, and thujone as anti-inflammatory compounds in a Salvia officinalis $L$. infusion using human gingival fibroblasts. J Agric Food Chem. 2013;61(14):3451-9.

193. Reuter J, Jocher A, Hornstein S, Monting JS, Schempp CM. Sage extract rich in phenolic diterpenes inhibits ultraviolet-induced erythema in vivo. Planta Med. 2007;73(11):1190-1.

194. Najafizadeh P, Hashemian F, Mansouri P, Farshi S, Surmaghi MS, Chalangari R. The evaluation of the clinical effect of topical St Johns wort (Hypericum perforatum L.) in plaque type psoriasis vulgaris: a pilot study. Australas J Dermatol. 2012;53(2):131-5.

195. Panahi Y, Sharif MR, Sharif A, Beiraghdar F, Zahiri Z, Amirchoopani G, Marzony ET, Sahebkar A. A randomized comparative trial on the therapeutic efficacy of topical aloe vera and Calendula officinalis on diaper dermatitis in children. TheScientificWorldJournal. 2012;2012:810234.

196. Szabo MA, Varga GZ, Hohmann J, Schelz Z, Szegedi E, Amaral L, Molnar J. Inhibition of quorum-sensing signals by essential oils. Phytother Res. 2010;24(5):782-6.

197. Shimelis ND, Asticcioli S, Baraldo M, Tirillini B, Lulekal E, Murgia V. Researching accessible and affordable treatment for common dermatological problems in developing countries. An Ethiopian experience. Int J Dermatol. 2012;51(7):790-5.

Ready to submit your research? Choose BMC and benefit from:

- fast, convenient online submission

- thorough peer review by experienced researchers in your field

- rapid publication on acceptance

- support for research data, including large and complex data types

- gold Open Access which fosters wider collaboration and increased citations

- maximum visibility for your research: over $100 \mathrm{M}$ website views per year

At BMC, research is always in progress.

Learn more biomedcentral.com/submissions 